\title{
Insurance for Legal Services: A Preliminary Study of Feasibility
}

\author{
Preble Stolz
}

This paper explores the feasibility of an insurance scheme, comparable to commercial health insurance, which would help the public, chiefly people of modest means, pay the cost of legal services. The idea of legal insurance has been around at least since the early 1950 's, ${ }^{1}$ but only once has a plan gotten far beyond the stage of talk. ${ }^{2}$ Recently there has been a resurgence of interest in the subject suffi-

Preble Stolz is Professor of Law at the University of California School of Law (Boalt Hall).

This study was suggested by the Special Committee on the Availability of Legal Services of the American Bar Association and commissioned by the American Bar Foundation. The analysis and conclusions are the author's sole responsibility. The study would not have been possible, however, without the assistance of Davis $\mathrm{H}$. Roenisch and William J. Quirk of Arthur Stedry Hansen, Consulting Actuaries, and access to early drafts of Group LEsAL SERvices (Tent. Draft 1967) by Barlow F. Christensen of the Bar Foundation Staff. Special acknowledgement is also due to Barbara Curran and F.B. Mackinnon of the Bar Foundation staff.

1 Brown, Legal-Cost Insurance, 1952 INs. X.J. 475, reprinted in 1961 INs. L.J. 84, is generally credited with being the originator of the idea. Another early contributor (including small businesses) was Barton, Legal Expense Insurance Plan-A New Approach, 1956 INs. L.J. 231. A panel discussion of the subject was held at the University of Southern California on May 18, 1957, and a mimeographed transcript of the discussion under the title Meeting Re: Proposal for Prepaid Legal Care can still be found in a few libraries. The American Bar Foundation published in mimeograph form two brief memoranda on the subject: L.A. Hale, Prepaid Legal Expense Insurance (Research Memo. Ser. No. 2, April, 1958) and E. M. Kjellenberg, Supplementary Memorandum on Prepaid Legal Expense Insurance (Research Memo. Ser. No. 9, March, 1960). The President of the California State Bar discussed the idea rather critically in Enersen, Group Legal Services, 35 CAL. ST. B.J. 11 (1960). The California State Bar Committee on Group Legal Services gave the idea a more sympathetic reception. Group Legal Services, 39 CaL. ST. B.J. 639, 715-722 (1964). Another brief contribution (which included contingent fee cases) is Sonneberg, Why Not Blue Scales for Legal Services?, 22 MILw. B. Ass'N Gaver 12 (1961), reprinted under the title Why Not Prepaid Insurance for Legal Services?, CASE \& CoM., July-Aug. 1963, at 36. See also Q. JoHnstone \& D. HOPSON, JR., LAWYERS AND THEIR WORK $544 \mathrm{n} .1$ (1967) [hereinafter cited as JohNSTONE \& HOPSON].

2 The Culinary Workers plan in Los Angeles, described in some detail in California State Bar Committee on Group Legal Services, Group Legal Services, 39 CAL. ST. B.J. 639, 670-74 (1964) [hereinafter cited as Cal. Bar Comm.] was abandoned largely because the union and management officials most concerned with it died and interest in the scheme disappeared with their absence. 
cient to justify a rather more careful examination of feasibility on the basis of information presently available.

A number of things have combined to cause this renewed interest in legal insurance. For some years the bar has been struggling with the general problem of the availability of legal services in part because the federal government has forced a vast expansion of legal services for the poor. The Supreme Court in Gideon v. Wainwright ${ }^{3}$ and related cases has compelled the provision of counsel for indigents in more kinds of criminal proceedings ${ }^{4}$ and at more stages of the criminal process. ${ }^{5}$ One arm of the War on Poverty has been the provision of legal services in civil cases to the poor through various forms of OEO-financed neighborhood and local legal service offices. This concern with providing legal service to people who heretofore could not afford it has stimulated interest in assessing the legal needs of the public generally and in devising new ways of meeting the need. ${ }^{6}$

The OEO Legal Services Program started largely on a foundation of assumed need for legal services by the poor, an assumption that its sponsors justified by redefining need and then proving that the existing institutions, primarily legal aid societies, did not attempt to meet the need as newly perceived. ${ }^{7}$ Even putting aside a modest skepticism based on Parkinsonian principles, the new OEO offices seem to be filling a genuine need. ${ }^{8}$ That experience with the poor has led to a comparable assumption that there is also a vast unfilled need for legal services for people of modest means. ${ }^{9}$

3372 U.S. 335 (1963).

4 In re Gault, 387 U.S. 1 (1967) (requiring notification of child's right to counsel in state juvenile delinquency adjudications).

5 E.g., Miranda v. Arizona, 384 U.S. 436 (1966) (requiring warning of right to counsel prior to in-custody police interrogations).

6 A new book, Johnstone \& Hopson, supra note 1, presents a number of carefully considered proposals for improving the quality and quantity of lawyers' work.

7 Cahn \& Cahn, The War on Poverty: $A$ Civilian Perspective, 73 Yale L.J. 1317 (1964) stated a need for advocacy on behalf of the poor that reached well beyond servicing the crisis needs of individuals. This theme has been carried forward by many others; much of the literature is cited in Carlin, Howard \& Messinger, Civil Justice \& the Poor, I L. \& Soc'y REv. 9 (1966).

8 Neighborhood Legal Services Programs, funded by OEO, handled 93,000 cases during the first three months of 1967. 2 LAw IN AcTion 1 (July 1967). By the end of fiscal year 1967, OEO had funded almost 800 law offices and 1600 full-time attorneys. Id. at 3. Not all of the offices are entirely new; some are expanded legal aid offices. Many, of course, are in communities which had no organized legal aid before.

- The middle class "need" for legal service also involves redefinition. The concept of "preventive" law has never caught on very well and much of the presumed "need" is of this character. See Brown, Law Offices of Middle-Income Glients, 40 CAL. ST. B.J. 720 (1965); Frankel, The Lawyer \&o the Middle-class, 39 CAr. ST. B.J. 385 (1964). 
There is no direct evidence that the middle class needs more legal service than it is presently getting. ${ }^{10}$ Citations can be collected stating that there is a need, but the sources cite each other, not broad, careful empirical research. ${ }^{11}$ Indubitably, many people think there is an unfilled need, and a persuasive case can perhaps be developed from reflecting about the growth and problems of modern society. ${ }^{12}$ With more people owning and transferring property today than ever before, for example, the likelihood of legal problems is greater. Government is bigger and the economic well-being of people is increasingly related to government benefits (welfare, social security, veteran's benefits) and the reverse: taxation. Other forms of government regulation, such as zoning, licensing, and environmental pollution restrictions, are increasing both in quantity and importance. Non-governmental institutions such as labor unions, professional associations and the like are also far more important than they used to be.

These conditions, it can safely be assumed, will generate more and more legal problems. We can also take it as given that lawyers are best equipped to handle many of the problems. ${ }^{13}$ But one more assumption is needed: that the middle class need for legal services is unfilled. If true, there must be some breakdown in translating the need for legal services into a demand for them. The profession has three explanations for this breakdown: (1) Many people do not rec-

10 Proof of this assertion requires review of what data have been collected. This has been attempted in P. Stolz, The Legal Needs of the Public: A Survey Analysis (Research Contribs. of Am. Bar Found. No. 4, 1968).

11 A bibliography of the literature on the subject is printed at the conclusion of $T$ he Availability of Counsel is Group Legal Services: A Symposium, 12 U.C.L.A.L. REv, 279, 456-63 (1965). See also B. Cerristensen, Group Legal Services 5 n.18 (Am. Bar Found., Tent. Draft, 1967).

12 Pincus, Legal Services for Persons of Moderate Means, 7 L. OfF. Econ. \& Manag. 235 (1966) apparently prefers this rather intuitive technique: "The usual technique in such surveys [none are cited] is to ask persons if they have consulted a lawyer, when, how often, for what purpose; if not, why not, etc. Every such survey shows that many persons have not used lawyers ever or very often; that there were some occasions when they might have; and that they might have paid a modest fee for such service. I suppose the failure of the legal profession to serve the public is conclusively demonstrated by the fact that it has not risen to this bait." Id., 236 .

Of course the surveys may be incorrectly overstating the need or understating the extent of lawyer utilization. And a number of people have suggested that the need may well be for cheaper legal services. See, e.g., JoHNstone \& Hopson, supra note 1, at 543-45. If true, that might also help explain the peculiar insensitivity of the profession to the need for its services.

18 This assumption is tolerable only if all kinds of problems are aggregated. For many government programs it may well be that internal administrative controls and other devices, such as the citizen advice bureau or "ombudsman," could well do a better job of assuring even-handed administration than extensive lawyer involvement on behalf of each applicant. 
ognize a legal problem when they have one; (2) even those who do identify a problem as legal are reluctant to consult a lawyer either because they do not know one; or (3) because they fear that it will cost too much. ${ }^{14}$

The first two stem largely from the ethical restrictions on advertising. Some efforts have been made through institutional advertising to demonstrate the kinds of things lawyers can do, especially in the preventive law area, and to publicize the availability of lawyer referral services. ${ }^{15}$ These responses to the problem of improving the availability of legal services have met with limited success.

The organized bar has recently become very much aware of another response: the emergence of what is confusingly called group legal services. ${ }^{16}$ The "group" in group legal services is composed of the purchasers of legal services, not the lawyers. Some forms of group purchasing of legal service are routine: trade associations, labor unions, and, of course, business concerns all regularly retain or employ coun-

14 See Cal. Bar Comm., supra note 2; Schwartz, Group Legal Services, 12 U.C.L.A.L. REv. 279, 284-91 (1965).

Another explanation is that the public profoundly distrusts the law and all of its institutions. There is considerable symptomatic evidence of this alienation: the traditional advice of the lawyer to avoid litigation at nearly any cost, the concern that traffic and other minor courts are undignified and dirty, the probable fact that people go to lawyers only when they have to, e.g., to get a divorce. See the Missouri Bar-Prentice-Hall Survey which attempted to probe the public attitude towards lawyers. Missouri BarPrentice-Hall, Inc., A Motivational Study of Public Attitudes \& Law Office Management (1963). Legal insurance is not going to overcome this fear of law and lawyers except possibly on a very long term basis. Conceivably, exposure to legal services (or at least to individual lawyers) would tend to encourage use. But cf. R. Huntrng \& G. NEUwIRTH, Who SUES IN NEW YoRK CITY? 72 (1962).

Yet another explanation is that the public is unwilling to pay the cost of legal services because they are in fact too expensive. See note 12 supra.

15 See Christensen, Lawyer Referral Service, 12 U.C.L.A.L. REv. 341 (1965).

16 There is no accepted definition of "group legal services." For some the phrase means that kind of selling of legal services which is prohibited by Canon 35. Others, notably the California Bar Committee which studied the subject, have used a more comprehensive definition which would include, for example, the retaining of counsel by a trade association to serve the needs of the association. A precisely analogous fog of definition surrounded the independent, closed panel medical service plans. In both cases the definition problem is at bottom political: those in the profession who oppose group legal services want it defined and understood as unethical, those who favor the idea want group legal services defined more broadly so as to emphasize the very narrow line that divides the ethical from the unethical. In this paper the phrase "group legal services" means providing legal services to individual members of a group (e.g., the membership of a union) by a lawyer or lawyers selected by the group to serve the individual legal needs of the members. The "model legal insurance" plan developed in this paper infra would not be a group legal service plan as so defined if the client had complete freedom in the selection of his lawyer. If the plan were organized, however, to limit the selection of a lawyer, as it could well be, see discussion in text accompanying note 154 infra, it would be a group legal service plan under this definition. 
sel, but the lawyer's services for these groups are restricted to representation in matters that are of shared concern to all the members of the group. What is distinctive about group legal service is that it reaches beyond the shared problems to serve the individual legal needs of the members of the group, needs that may be wholly unconnected with interests of the group.

Very few group legal service plans are presently operating. Those that are have, for the most part, restricted themselves to representation in particular kinds of proceedings, for example, workmen's compensation. There have been a few tentative beginnings of broader schemes. The reason for the very slow growth has been the position of the organized bar which has held that form of selling legal services unethical under Canon 35.17 Recently the United States Supreme Court in United Mine Workers District 12 v. Illinois State Bar Association, ${ }^{18}$ held this position of the bar an unconstitutional invasion of rights of petition and assembly in an opinion which will, at a minimum, make it difficult to use the existing ethical norms as a way of prohibiting group legal services. ${ }^{19}$

Group legal services has a considerable potential as a way of overcoming the obstructions that presently inhibit the middle class demand for legal services. If a labor union, for example, sets up a group legal service office, it could easily conduct educational programs that would help its members identify legal problems. By definition the group would supply the lawyer to serve the needs of members, and group legal service could ease the financial problem that may discourage some from seeing a lawyer.

Group legal service is like legal insurance in that it spreads the cost of legal services among all the members of the group. However, a legal

17 The California State Bar Committee on Group Legal Services discusses the history of the bar's position. Cal. Bar Comm., supra note 2, at 690-701. See also Cedarquist, Lawyers at the Crossroads-Profession or Trade?, 31 Unautr. Prac. News 79 (1965). The second paragraph of Canon 35 provides: "A lawyer may accept employment from any organization, such as an association, club or trade organization, to render legal services in any matter in which the organization, as an entity, is interested, but this employment should not include the rendering of legal services to the members of such organization in respect to their individual affairs." ABA CANONs of Professional Ethics No. 35.

18389 U.S. 217 (1967).

19 Now that sweeping prohibitions on group legal services have been held unconstitutional it is possible that the bar may attempt to impose more detailed restrictions on the formation and operation of group legal service offices. If the experience of medicine is relevant, these may well serve to frustrate or at least delay the extensive utilization of group legal services by the public. B. Christensen considers some potential ethical norms for group legal services in Group Legal Services 54-66 (Am. Bar Found., Tent. Draft, 1967). It should be added that his proposals are not obstructive in intent. 
insurance plan, unlike group legal services, could be organized to permit the client-insured to select his own lawyer, who would be compensated by benefits from the insurance policy. Legal insurance's capacity to preserve the client's choice of his own lawyer explains much of the current interest in the feasibility of legal insurance. Some of the professional hostility towards group legal services is doubtless rooted in fear of the competitive consequences if group legal services become common. The bulk of the bar is in individual or small firm practice, and if large blocks of the public had their legal problems channeled to group service lawyers, the competitive consequences might be devastating. Legal insurance would have much less serious consequences because people would still be picking their own lawyers, and it might well improve the financial position of individual and small firm practitioners to the extent that people used lawyers more often and paid them more regularly.

Legal insurance of itself is not going to help people identify problems as legal or guide them to a lawyer. It might help overcome the reluctance of people to consult a lawyer because of fear of the cost. If legal expenses of the middle class were substantial and very unevenly distributed, legal insurance, by spreading the cost among the group, could increase the amount available for the few times it was needed and, at the same time, reduce the cost to the individual. This is the classic function of insurance; by pooling risks the individual risk of loss is reduced. Unfortunately, the legal problems of the middle class are overwhelmingly not of a low-frequency, high-cost nature. Rather, as will be shown later, the middle class apparently needs legal services that do not cost very much and that are very widely distributed. Financing these expenses through insurance will not reduce the cost to any individual; indeed, it will increase the total expense because of the cost of administering the insurance program. But legal insurance could still help overcome resistance based on fear of the cost of consulting a lawyer, since people would be more likely to consult a lawyer about matters they thought might have legal implications if they had already paid for his services through insurance. The proposal of legal insurance is thus much more a plan for prepaying or budgeting the expense of legal services than it is a device for pooling the risk of heavy loss through insurance. ${ }^{20}$

20 There is a terminology problem here: some would say that this should not be called insurance at all but rather prepayment of legal services. The ideas are occasionally merged in the term "prepaid legal insurance" which evokes the right idea but in insurance terminology has a technical and quite different meaning. For marketing purposes "insurance" is clearly best, albeit inaccurate, and, for convenience, that word is used throughout this paper. 
The feasibility of legal insurance is a complex question that cannot be conclusively answered until someone tries it. Thinking on the subject has been dominated by the parallel of health insurance: If the doctors can do it, why can't the lawyers? It may be well to confront that question directly at the outset because the analogy is false and the sooner it is put out of mind the better. Many things, of course, distinguish medicine from law, but in terms of insuring the cost of professional services, two are critical. First, everyone confronts the near certainty of serious medical expenses at some point in his lifetime and a substantial risk of catastrophic loss. ${ }^{21}$ The middle class has no comparable risk exposure for legal service costs because the most common serious legal involvements are presently covered through liability insurance for defendants or a contingent fee for plaintiffs. ${ }^{22}$ Second, health insurance has been built on a base of protecting against institutional charges, particularly hospital costs. ${ }^{23}$ These and other charges for specialists, surgeons for example, permit health insurance to provide partial coverage fairly easily; in general the last and most difficult item to insure against is the professional fee of doctors, especially for routine services. ${ }^{24}$ In contrast, nearly all legal service charges are for the professional services of the lawyer.

21 This truth is reinforced by the usual practice of insuring the family as a unit rather than individuals.

22 This point is discussed further in Section IB infra.

23 The stimulus for the development of hospitalization insurance came largely from the private hospitals. During the depression they were in desperate need of additional revenue because they confronted both rising costs and a loss of income from patients and philanthropy. Their willingness to underwrite the initial experiments was an indispensible ingredient of the ultimate success of the Blue Cross plans. The history of the growth of the hospitalization plans is comprehensively discussed in H. SOMERS \& A. Somers, Doctors, Patients, and Health Insurance (1961).

24 The classic form of insurable event is one that is objectively verifiable, of random but predictable incidence, and with a specified value. It is not an event in the control of the insured or, at the minimum, it is an event highly undesirable to the insured. Furthermore, the risk insured against should be substantial enough to disrupt seriously the financial position of the insured.

Some kinds of medical expenses come close to this definition. Insurance companies started with limited benefits for medical expenses associated with accidents; there the incidence was predictable by the precipitating event, and the fixed monetary benefit restricted the liability. Hospitalization expenses are not precisely analogous; to some extent they are subject to control of the insured (and for these purposes the physician is also an insured), but few want to go to the hospital, especially for surgery. Perhaps the next most insurable event is the professional fee and other costs of surgery. Surgical procedures are not lightly undertaken (although the two most common, appendectomy and tonsillectomy, are subject to abuse), and most surgical operations involve discrete events of a repetitive nature where the fees are not likely to vary much from one patient to another and benefits can be controlled by a schedule of benefits for various procedures.

Other medical care expenses are less desirable from an insurance point of view. 
Furthermore, the spectacular growth of health insurance ${ }^{25}$ is largely attributable to two factors which lack effective counterparts in law. First, the vast increase in the demand for and cost of medical care led to the threat of government sponsored compulsory health insurance. Organized medicine resisted that threat by throwing significant support to private health insurance as an essentially conservative response to the danger of a far more radical restructuring of the economics of medicine. ${ }^{28}$ Group legal services presents a somewhat comparable threat to some lawyers. If group legal services ever develops, it may stimulate some support for legal insurance plans that will preserve the client's free choice of lawyer. But the organized bar is unlikely to care as much as organized medicine did because the practice of many of the more influential members of the bar would be wholly unaffected by the extensive use of group legal services. Second, the public, and particularly

Some of them are not worth insuring against since they are very modest in expense (e.g., the annual medical examination, preventive pediatric care); some are highly subject to abuse by the patient (e.g., the first visit for an illness, cosmetic surgery); some are highly subject to over-utilization by the doctor (e.g., laboratory tests, specialist consultations, drugs); some have rather vague limits on when the insured event occurs or has been completely treated (e.g., mental illness).

These facts are reflected in the coverage of health insurance. About $70 \%$ of the population have some form of hospitalization insurance, $65 \%$ have surgical protection, $\mathbf{5 5 \%}$ have "regular" medical insurance which usually covers only in-hospital non-surgical physician fees. The percentage of coverage declines rapidly thereafter: $35 \%$ have some coverage of $\mathrm{X}$-ray and laboratory examinations in physicians offices; $31 \%$ have some coverage of physicians' home and office visits; $25 \%$ have some coverage of prescribed drugs, private duty nursing and visiting nurse service; $3 \%$ have some coverage of the costs of nursing home care. Most of these last items are covered only as part of major medical coverage which provides protection only after the insured has paid an initial amount (deductible) per illness or year. These figures are taken from L. Reed, The Extent of Health Insurance Coverage in the United States (Off. Research \& Statistics, Soc. Sec. Ad., U.S. Dep't of H.E.W., Research Report No. 10, 1965).

Dr. Reed's analysis is based on data as of December 1962, and his figures thus antedate both Medicare and a very considerable growth of major medical coverage since then. Current figures can be found in Health INSURANCE INSTITUTE, SOURCE Book of HeAlTH Insurance Data (1966). Dr. Reed's analysis suggests some caution in using HII's figures, which he believes tend to overestimate coverage.

25 Private health insurance, initiated in 1933, now reaches over two-thirds of the population, but it is still some distance from paying the bulk of private expenditure for medical care. In 1962 health insurance met about $31 \%$ of the total consumer medical care expenditure, not counting the cost of obtaining insurance. L. REED, supra note 24 , at 42 . Slightly more than $34 \%$ of the private expenditures for physicians' services were in the form of insurance benefits, again excluding insurance costs. This percentage figure is derived from U.S. Dep'T OF COMMERcE, BuREAU of The Census, Statistical Agstract of the UNtred States 71, tab. 84 (1965).

26 J. Garbarino, Health Plans and Collective Bargaining (1960) [hereinafter cited as Garbarino] gives a full historical account of the California Physicians' Service, one of the early and most overtly political of the physician-sponsored health insurance plans. See also Comment, The American Medical Association: Power, Purpose, of Politics in Organized Medicine, 63 YALE L.J. 938 (1954). 
organized labor, is deeply concerned about access to medical services; that, of course, explains why compulsory health insurance was an important political issue. Labor lost the battle for government involvement in medicine but it won substantially equivalent benefits for its membership through collective bargaining for health insurance as a fringe benefit. Labor officials have no difficulty sensing that their membership cares about medical services to a far higher degree than they do about legal services. That reflection of public interest is not likely to change significantly in the near future.

If the question of the feasibility of legal insurance is seen in terms of the parallel of health insurance, the answer has to be that it is not possible to design an insurance system for law that has any real promise of providing a level of service or protection comparable to that afforded by health insurance. That is not, however, the only way to frame the question. A much more modest objective could be sought. A legal insurance scheme could be designed with the chief goal of providing a convenient way to budget relatively modest, frequently encountered legal costs. On that base of budgeting, it would be possible to add some insurance protection against infrequent, serious but not catastrophic losses. The primary social utility of such a budget-insurance package would be that it would encourage people to consult lawyers early, at a time when their problems might be avoided or at least minimized. That may well be worth doing. Certainly reasonable men could conclude that it was worth a try. In this limited sense, legal insurance appears feasible.

\section{Problems of Planning and Underwriting}

\section{A. Some Basic Problems}

The following section focuses on four general characteristics of the practice of law which make difficult any system of financing legal services through insurance. They are: (1) determining who is the insured; (2) overcoming the uneven distribution of need for legal services because need is powerfully influenced by the wealth of the insured; (3) determining the benefit in the face of the vagueness of the concept of legal services; and (4) protecting against "abuse" by lawyers and clients when the amount of legal services is chiefly regulated by the value of the interests involved. None of these problems is insuperable but their solutions force legal insurance to be at best of relatively limited scope.

1. Business vs. Personal Legal Services-Who is the Insured? Regardless of whether doctors are employed by an individual or some third party, there is rarely any difficulty in determining who is the beneficiary 
of the doctor's services; or, in other words, who is the insured. That is not true of law. A major portion of the income of lawyers in private practice is derived from business or commercial clients, not individuals. ${ }^{27}$ In discussions of legal insurance, the assumption has always been that only "personal" legal expenses would be covered, and that business corporations, for example, would not be offered any comparable kind of policy. ${ }^{28}$

The assumption that commercial concerns would not have access to legal insurance is probably sound. Business clients can now buy a form of legal insurance by employing house counsel directly or by retaining a law firm. To some extent the law firm on a retainer underwrites the risk that the client will have unusually heavy legal expenses. Employing house counsel provides a comparable kind of protection, limited by the work capacity of the lawyers. ${ }^{29} \mathrm{~A}$ second reason for excluding business clients from legal insurance is the nearly impossible problem of protecting against adverse selection. The legal problems of a business are very largely in the control of the persons who manage it. They can choose legally hazardous enterprises, and presumably the choice of purchasing legal insurance would be controlled by whether or not they thought their conduct likely to make it worth it. In other words, little is random about the distribution of risk of legal expenses among business enterprises.

If the legal expense of commercial activity is to be excluded, how can personal legal expenses be distinguished from business legal expenses? A hypothetical insured client illustrates the dimensions of this problem: the insured is covered because he is a union member and an employee of a company. He invests his savings in a small apartment building. Are the legal expenses associated with the building's acquisition

27 F. B. Mackinnon of the American Bar Foundation has collected and analysed the available figures and reaches the tentative conclusion that about half of the income of lawyers in private practice is derived from business clients. F. B. Mackinnon, The Market for Legal Services (unpublished manuscript, 1966).

28 But see Barton, Legal Expense Insurance Plan-A New Approach, 1956 INs. L.J. 231.

29 Commercial concerns, of course, have access to other forms of legal insurance which turn on the precipitating event, e.g., workmen's compensation insurance usually includes coverage of legal expenses incident to claims, and the same is true of automobile insurance. Some kinds of legal service involve a serious risk to a business concern only if the cost will put an individual commercial concern in an unfair position vis-à-vis its competition. This problem can be and is solved by employing counsel through a trade association. Thus, legal expenses associated with collective bargaining (if done on a multi-employer basis) or lobbying are spread evenly among firms by using a trade association as the client. These arrangements do not decrease the risk of loss to any particular concern, but they protect against disproportionate expense to a single concern in relationship to its competition. 
covered? What of the fees involved in processing a zoning variance for the apartment building? An elderly aunt of the insured has recently lost her husband and wants the insured to manage her modest investments. Are the legal expenses associated with setting up a trust and administering it covered? The wife of the insured (whose legal expenses would presumably be covered as a dependent) wants to set up a small nursery school in her home and needs help in processing an application for a license from the Public Health Department. The insured wants help in preparing his tax return which necessarily will include problems connected with his apartment building and his wife's nursery school. Are any of these legal services covered?

A comprehensive system of legal insurance would include all of these, but to do so would involve the same dangers of adverse selection presented by insuring legal services for business clients. Probably the only way of distinguishing personal from business expenses would be to borrow the same line drawn in income tax law by covering only those legal services which were not deductible as a business expense of the insured. Thus the legal expenses associated with the apartment building and the wife's nursery school would not be covered. The virtue of using tax distinctions is that in general it would be self policing because the taxpayer-insured would usually benefit more by treating his activities as non-personal than by claiming insurance benefits. This distinction would not solve the mingling problem inherent in the fictional nature of the personal-business distinction as illustrated, for example, by the preparation of tax returns which can easily have elements of both in it.

This is one of the largest and most intractable problems inherent in any broad scheme for insuring the cost of legal services. So long as the insurance scheme is limited and the benefits relatively small, the problem of determining who is the insured is containable. It will become very large, however, in any broad, generous plan of legal insurance because of the law's willingness to recognize fictional entities and the general practice of pooling resources for all sorts of purposes-from forming business corporations to buying vacation property. Any time the benefits become substantial, the business-personal line will have to be maintained to protect against adverse selection, and the line will invariably be difficult to draw and hard to police.

2. The Need for Legal Services as a Function of Wealth. Health insurance planning is facilitated by the fact that, apart from age, sex, and to a lesser extent occupation, the incidence of sickness is evenly distributed throughout the population. ${ }^{30}$ That is not true of legal prob-

30 Age and sex are used in calculating the premium for individual health insurance, 
lems, which in large part cluster around property ownership. The more property a person has the more likely he is to have legal problems, and the more valuable the property interests the more complex the legal problems are likely to be. Unless the property ownership of the class being insured is quite homogeneous, the rich will get a disproportionate amount of the legal insurance benefits.

It is very difficult to know how serious this problem is. It may be that the incidence would be significantly different only as between the very rich and the very poor. ${ }^{31}$ On the other hand, there is some evidence which suggests that the difference would be substantial between the upper and lower middle classes. ${ }^{32}$ Assuming that the problem is substantial, there are three insurance devices that could be used to meet it. One would be to exclude benefits for those kinds of legal services such as estate planning where the incidence differential is highest. Another alternative would be to limit the benefits to an amount adequate to compensate the lawyer handling a routine case for persons with modest means, thus making the person with a more complex problem a coinsurer of the risk. For example, the benefit for divorce could be limited to a sum sufficient for a simple divorce without any property settlement. In general that will tend to provide people with a kind of protection they do not much need and give them no protection against the larger legal expenses. The third way to meet the problem is to vary the premium according to the wealth (possibly measured by income) of the insured. This could be done initially by offering insurance only to groups with a very limited range of incomes, or by concealing differential premiums by offering a number of plans with different levels of benefits so that, for example, coverage of real estate transactions would be limited to a very small benefit without the payment of an additional premium.

and the mix of age and sex is used in determining the premium for any group insurance plan. These are easily determined, especially in contrast to wealth. Most people know their age and sex, few know their net worth. Furthermore, some kinds of property ownership are doubtless more productive of legal problems than others.

31 The most careful study, now 30 years out of date, refused to draw any conclusions on this point, Clark \& Corstvet, The Lawyer and the Public: An A.A.L.S. Survey, 47 YALE L.J. 1272, 1278 (1938). They found a "somewhat" higher use of outsider advice by those people who had incomes over $\$ 2,000$, but they thought their sample too small to warrant general conclusions.

32 The findings of E. Koos, The Family \& the Law (mimeo. 1949) suggest that there is a vast difference between the "working class" and "middle class" groups in the kinds of problems they have. His results indicated that most landlord-tenant problems are "working class" problems; most real estate and inheritance problems concern the "middle class." The results of his study, along with an analysis of his methodology which would suggest caution in extrapolating his results, can be found in Stolz, supra note 10 . 
3. What are Legal Services? Some legal services are fairly welldefined. For example, what a lawyer should do in handling a default divorce is clearly understood within the profession. Within a fairly narrow range, the amount of time one experienced lawyer would spend on the case is the same as any other, and it would probably be possible to calculate a standard benefit for that legal service. This is also true with the preparation of some kinds of legal documents. The minimum fee schedules suggest the areas where this is possible. However, the further we go from the areas where lawyers have a legally protected monopoly, the less clear become the boundaries of legal services. Two factors dominate how a lawyer reacts to a client's problem outside of the standard legal service areas: (1) the client's wishes for assistance, and (2) the lawyer's perception of what he can do that will be useful and that will be worth the charge he will have to make.

How much a client wants or needs in the way of legal services will be closely related to his own level of sophistication. Nothing in the ethics of the profession prevents a lawyer from giving all kinds of advice, much of which may have little to do with law. For example, a lawyer is expected to probe his client's reasons for wanting a divorce and to work towards effecting a reconciliation if he thinks that possible. The lawyer may be asked not only to review the technical problems involved in buying a home, but also to advise on the wisdom of the transaction considering the client's resources and needs. With unsophisticated clients (the classic case is the recently bereaved widow) a lawyer can find himself giving all sorts of financial and personal advice.

What is law practice is thus very ill-defined. The authority all comes from the other direction-the bar's effort to preserve its monopoly position. If non-lawyers such as banks or accountants provide a counseling service or attempt to perform some other tasks within the legally protected monopoly of lawyers, the bar has sought to restrain them. ${ }^{33} \mathrm{But}$ there is no professionally recognized limit as to what a lawyer can do, no well established boundary that defines when a lawyer stops being a lawyer and starts being something else. There is nothing unprofessional or improper in a lawyer charging a fee for professional services for doing something that a bank official could do as well.

The principal restraint on a lawyer is his client's capacity to pay fees. In general the hourly charge for a lawyer's service is high enough to discourage consultation on any matter other than those that are very significant to the client, and the lawyer is as aware of this as the client. Any system of legal insurance which pays a portion of the fee for con-

33 The unauthorized practice literature is vast. It is collected in UNAUTHORIzED PRACTICE SOURCE BOor (S. Bass ed. 1965). 
sultation will obviously have an effect on the extent to which clients feel free to seek advice. Similarly, the lawyer will have a harder time discouraging non-legal consultation.

This is a major problem from an insurance point of view. Many legal problems are not of an objectively verifiable nature. The need for legal services outside of the "standard" areas is thus defined by the client and the lawyer, both of whom are the beneficiaries of the insurance plan in this context. This creates a policing problem made more complex by the sacred character of the confidential relationship between lawyer and client. Any reviewing body would have to know the subject matter of the consultation in order to evaluate the legitimacy of claims for benefits, an intrusion which the bar is not likely to accept. ${ }^{34}$ Probably the only way to meet the problem of abuse is to limit the benefit for consultations very sharply so that, for example, only one consultation per year would be covered, and to abandon any attempt to police.

4. The Cost of Legal Services as a Regulator of the Quantity and Quality of Legal Services. The concern here is related to the two preceding problems, but is a separate and basic problem of legal insurance. Legal problems are not spread evenly because the number of legal problems any individual has depends mainly on his personal wealth. Since there is no clear definition of what constitutes legal service, it is difficult to determine for what benefits are to be paid. But even if these two factors are held constant by assuming that some solution can be found for the uneven distribution of legal problems and limiting attention to services that are clearly legal, there remains the essential diffculty that in very large part the amount of legal service devoted to any problem is a function of the value of the interests involved. This is indirectly stated in Canon 12: "In determining the amount of the fee, it is proper to consider: . . the amount involved in the controversy and the benefits resulting to the client from the services...." Although stated as determining the amount of the fee, the value to the client frequently determines the amount of work that the lawyer does and thus the fee, much more than the other way around. Most legal matters are easily converted into dollar values, although there are important exceptions. The rights of liberty (i.e., not to go to jail) and free speech are quite properly described as priceless, and the same could be said

34 The various fee financing schemes require the lawyer to identify in the most summary way the services for which the loan is being extended. Even that minimal degree of disclosure is resented. See note 128 infra. The English, on the other hand, have no difficulty in requiring an applicant for legal aid to spell out in detail the nature of his problem to a committee of soliciters which must certify the case as meritorious before the applicant is eligible for legal aid. JoHnstone \& Hopson, supra note I at 514-15. 
also of the somewhat less cosmic rights to marry or to divorce or to go into bankruptcy. But most legal rights relate to property, and most property rights have a dollar value. Legal problems are not fungible; and, in very large part how much time a lawyer devotes to a problem depends on how much the client is willing to spend, which in turn depends on how much money is involved. ${ }^{35}$

It would be a mistake to think of this as evil. It reflects the general economic principle that it is a misallocation of resources to use expensive legal talent to unravel problems that involve a small amount of money. In some instances this reasoning has been deliberately violated because certain kinds of claims are thought to have special value. For example, the district attorney is in most states charged with the responsibility of collecting child support from deserting fathers. ${ }^{36}$ Private lawyers could not economically provide that service because the sums involved are too small. Similarly, in many states an agency is given the task of enforcing claims for unpaid wages. ${ }^{37}$

The rationale behind Legal Aid is more complex. There is a tendency to talk in terms of the value of justice itself, which may be misleading outside the area of legal rights that do not have an obvious dollar value. A case can certainly be made that a poor man ought to be able to have the same access to a legal divorce as a rich man, but it is not as obvious that a poor man should get free legal service for a $\$ 200$ claim while a rich man should get nothing. Some argument, however, can be made that the marginal value of a small claim to a poor man is so much greater than for a rich man that the dollar equivalence of the claims is not a fair measure of their significance to the parties. For example, if the wage garnishment for a $\$ 200$ claim is not lifted, the poor man may well be without funds to pay for necessities, and the value to him of prompt and inexpensive legal service is much greater than the prosecution of claims for far larger amounts is to other people. Furthermore, there is evidence that the very poor as a class tend to be

35 The law prides itself on being a profession not a business. This discussion should not be interpreted as inconsistent with that ideal. There is a minimum level of service which a lawyer is obliged to perform. Even if he cannot charge or collect a fee appropriate to that minimum service, having accepted the case a lawyer is nonetheless under an obligation to perform that much. The problem here is not with the minimum service, but with the absence of any restraint, other than economic, on the maximum service which a lawyer can appropriately render. Above the minimum level, it is the value of the interests involved that determines how much work the lawyer does.

36 E.g., Cal. Crv. Code $\$ 139.5$ (West Supp. 1965); Irl. Stat. ANN. ch. 68, \$\$ 24-24b (Smith-Hurd Supp. 1966); N.Y. FAM. Cr. Acr \& 254. For out-of-state cases, the Uniform Reciprocal Enforcement of Support Act, 9C U.L.A. \& 12 (1966 Supp.), similarly provides for representation by the local prosecuting official.

37 E.g., Gal. LAbor Code § 92; Ill. Stat. ANN. ch. 48, § 39l; N.Y. LAB. LAw § 199. 
oppressed by sharp practices, ${ }^{38}$ and there is thus a social utility in providing them with free legal service.

The problem, however, is much broader than just the small claim situation because lawyers adjust the level of service they provide to the value of the interests involved. A client's problem involving $\$ 500$ will get an "off the top of the head" opinion; if it is a $\$ 10,000$ issue, some research in the statutes will be done; and if it is a $\$ 1,000,000$ SEG registration, the problem will be exhaustively researched and the client billed accordingly. As mentioned above, the amount of legal service devoted to any problem is a function of the client's willingness to pay, and that in turn is a function of the amount of money involved. To phrase the same point somewhat differently, the amount of legal service that can be given to any particular problem is very largely open-ended. If there is enough money around, a lawyer can devote an almost endless amount of time to perfecting a legal position and, indeed, is expected to do so.

In these respects law is considerably different from medicine. In the first place, sickness in general does not lend itself to assessment in terms of dollars. There are some minor ailments as to which one can say that it is not worth a doctor's time, but for the bulk of serious matters one does not think of sickness as having monetary value. Perhaps because the patient is much less able to evaluate his need for medical care, medical ethics speak quite directly to the problem of overtreatment, and these ethical norms are supported by the general shortage of physicians and the resulting absence of temptation to provide unneeded services. The extensive use of specialists and the physical necessity for using hospitals also provide informal checks against overutilization. Legal ethics are wholly silent on the issue of overutilization; almost total reliance is placed on the client's unwillingness to pay for unneeded services to protect clients from overcharging.

The cost of legal services is the chief method of regulating the quantity and quality of many kinds of legal services. Insuring that cost has an obvious potential for distorting the amount of legal services given to any particular situation, a distortion that is, on the whole, undesirable. This can be seen perhaps most readily in the small claims context. Legal insurance will encourage the use of lawyers in instances when the value of the service is disproportionate to the value of the underlying claim. The social value of that is doubtful for two reasons.

First of all, it is a violation of the general economic principle that expensive services should pay their own way. If the parties would not spend their own money in enforcing their claim with lawyers, do we

38 See, e.g., D. Caplovitz, The Poor Pay More (1963). 
want to create a system that would spend, in substance, other people's money for that purpose? Second, providing what amounts to subsidized legal service to one side is very unfair to the other side, especially in settlement negotiations. Quite apart from the merits of a plaintiff's claim, a defendant will generally be well advised to settle for any amount less than what it would cost him to defend. Automobile liability insurance companies are familiar with this and speak quite directly of the "nuisance" value of a suit. A comparable phenomenon was recently seen in the English Legal Assistance Act. In England the losing party to litigation is required to pay the legal fees of the successful party. Under their Legal Assistance program, if a person successfully defended a claim brought against him by an assisted plaintiff, the unassisted defendant frequently found himself with an uncollectible claim for lawyer's fees. To overcome this unfairness, the program was recently expanded to authorize payment of the defendant's lawyer's fees in the event that an assisted plaintiff lost. The end result is that the program now subsidizes the legal costs of both sides, a frank recognition of the public value of resolving private disputes and tolerable because all applications for assistance are screened in advance and the fee system is very strictly regulated..$^{39}$

The distorting potential of legal insurance is not limited to the small claim situation. The presence of legal insurance will affect not only the client's perception of when he wants to use legal service; it will also influence the lawyer's decision as to the amount of legal service to provide. The potential effect of legal insurance can be seen, in the abstract at least, by positing a hypothetical client with a contested claim for $\$ 10,000$. The lawyer's fee in that situation will be determined by a complex calculus that discounts the probability of success by the lawyer's charge..$^{40}$ The more work the lawyer does on the matter, the more likely he is to prevail, but cleariy it would be of no benefit to the client if the lawyer did $\$ 10,000$ worth of legal work because the client would gain nothing if the matter were won and would run the risk of losing both his claim and incurring a loss of $\$ 10,000$ in legal fees. On the other hand, if the lawyer did nothing or very little, the claim would almost certainly be lost. Somewhere in between, an optimal point is reached where the increased probability of success justifies the investment in so much and no more legal service. If the lawyer and client

30 Johnstone \& Hopson, supra note 1 , at 516.

40 Other factors can also influence this judgment; for example, the reputation of a frequently-sued defendant can justify spending more than the value of a claim against him to discourage nuisance claims of others. A "test" case similarly will call for a large overexpenditure in terms of the particular case because of its potential stare decisis effect. 
would normally agree that the optimal point is reached with a legal fee of $\$ 1,000$, this means the lawyer will do as good a job as he can for that amount of his billable time. If the client had insurance that paid 50 per cent of the lawyer's charge, the effect would be to permit the lawyer to charge $\$ 2,000$ because the possibility of success in this case would still be worth an investment (by the client) of $\$ 1,000.41$ Presumably the client would get twice as much legal service because he has legal insurance, but it is doubtful that he bought legal insurance for that reason or that such "doubling" of legal service is a good idea as a matter of allocation of economic resources. ${ }^{42}$

In insurance terminology these problems are problems of abuse, of using the proceeds of insurance to pay for something that the insured would not buy if it were not for the insurance benefit. ${ }^{43}$ Although, as noted earlier, medical care is relatively insensitive to this kind of abuse, the problem has nonetheless been a difficult one for health insurance. Excluding from coverage the first or second visit to the doctor is the health insurance answer to the problem of minor ailments, a problem closely analogous to the small claim dilemma of legal insurance. Exclusion of first dollar expenditures is unfortunate in that it tends to discourage early consultation when the possibilities of cure may be greatest. The same thing would, of course, be true with legal insurance, because the critical financial obstacle to preventive law would remain.

One possible way of meeting the small claim problem would be to limit the benefit to consultation with a lawyer. ${ }^{44}$ This would give every

41 This assumes that each additional dollar invested in legal work will have an equivalent effect on the probability of success. Obviously this is not true; even lawyers recognize that the law of diminishing returns eventually reduces the value of additional work to nothing. For lawyers, however, that point is rarely reached. For many lawyers, most of the work they do is at the minimum level of adequacy, and in that situation the marginal utility of an additional investment is probably quite close to the value of the initial investment in legal services.

42 Of course, the long range result would be an increase in premiums sufficient to price the whole plan out of the market.

43 This is not a satisfactory definition of abuse, especially since one of the major purposes of legal insurance is to encourage people to use lawyers. Health insurance has the same problem. Professor Garbarino has classified four kinds of abuse in health insurance: "(1) The provision of unnecessary medical services, (2) the provision of excessive amounts of necessary services, (3) the provision of a necessary service in the hospital when it could have been performed outside, and (4) the charging of excessive fees." Garbarino, supra note 26, at 51-52. The small claims problem is analogous to (1); the $50 \%$ hypothetical is analogous to (2); (3) is unique to the health insurance context, and (4), the overcharging problem, is discussed at text accompanying notes 111-112 infra.

44 Where the damages are fixed in contract claims, a minimum monetary claim could be used, perhaps the maximum jurisdiction of the small claims court. That would not work for most kinds of tort claims, in which the size of the claim depends on the claimant and his lawyer. 
insured the opportunity to consult with a lawyer for help in evaluating the legal sufficiency of his position and to assist him, if needed, in conducting informal negotiations. Beyond that level of service, however, the insured would not receive any insurance benefit unless he was either in the position of defendant or his claim was of a class as to which the benefit was controllable in other ways. This would have the virtue of providing the insured group with some legal advice without encouraging lawyer involvement or litigation which is economically false.

This solution may provide some protection against client abuse; it does nothing to protect against lawyer abuse of providing more service than, economically speaking, the problem deserves. Again health insurance can meet physician abuse relatively easily. ${ }^{45}$ The surgical schedule, for example, is a recital of more or less standard fees (or percentage of fees) that are in the main uniform and do not vary much from patient to patient. Bar association minimum fee schedules might provide a similar solution for legal services that are routine and repetitive. But even here, with such things as an uncontested divorce, the amount of time a lawyer can honestly spend on the case is quite open-ended. The very narrow scope of the minimum fee schedules is perhaps more important because most services are covered only indirectly through the minimum hourly charge or day-in-court charge.

The health insurance device to protect against physician abuse is co-insurance. Making the patient pay a significant percentage of the cost will tend to discourage the doctor from inflating unduly the amount of medical services. That system will not work with legal insurance because in many instances the lawyer's assessment of what he ought to do for the client depends primarily on the dollar value of the case to the client. As suggested earlier, affording a 50 per cent of cost benefit will often mean in many instances twice as much legal service, with the client paying exactly the same amount as he would have paid if he had not had any legal service insurance.

There is no easy answer to this problem. Undoubtedly, there is some vague standard of what is an appropriate amount to charge in any situation, which would serve to restrain at least some lawyers from abusing the system as much as the 50 per cent hypothetical suggests. The greatest area of potential abuse is between the initial consultation and the courtroom. Once in court a number of forces tend to limit the amount of service a lawyer will provide. The trial judge has some interest in expediting litigation before him, and the strain on parties and witnesses and the demands of effective advocacy will all discourage prolix trial presentation. It would be possible to restrict benefits to the

45 "Relatively" is an important word. See Garbarino, supra note 26, at 49-86. 
initial consultation and services rendered in court, leaving the insured to pay the costs of extended research, advice and trial preparation. This could be thought of as analogous to insuring the professional costs of surgery, with the courtroom the equivalent of the operating room. The disadvantage, of course, lies in the substantial amount of legal services which would not be covered. The only practical alternative is to regulate fees-a suggestion unlikely to be received warmly by the bar, although it is worth noting that lawyers' fees in England are either specified by a schedule, or, to the extent they are not, are subject to review by the Law Society. ${ }^{46}$

\section{B. Legal Insurance for Specific Kinds of Legal Services}

Thus far the examination of legal practice has been general; what follows is a close look at specific kinds of legal problems to evaluate the potential impact of legal insurance. For these purposes, three issues are of repetitive concern: (1) is insurance or something like insurance presently available to finance this kind of legal service; (2) is there social utility in legal insurance in this context; and (3) are there any better ways of accomplishing the objectives of legal insurance? ${ }^{4 t}$

1. Civil Tort Litigation. Legal insurance is now generally available in an action involving the operation of a motor vehicle or the ownership of real property. ${ }^{48}$ Automobile and householder liability policies provide that the insurance company will assume the defense of any suit (meritorious or not) against the insured concerning the property. Unless the plaintiff's claim is in excess of the policy limits or the insured wishes to present a counterclaim, this protection is usually adequate. In the latter cases, which are relatively rare, counsel for the insurance company may have difficulty adequately representing both the company and the insured, whose interests, especially in settlement discussions, may conflict. Counsel for the insurance company in these situations should advise the insured to retain his own counsel. ${ }^{49}$

\footnotetext{
46 JoHnstone \& Hopson, supra note 1, at 496-501.

47 The alternative of financing through group legal services is always present. That alternative is discussed generally in text accompanying notes 137-151 infra.

48 Automobile cases represent the bulk of these cases. In 1960 insurance companies paid out $\$ 1,494,000,000$ in automobile personal injury claims and only $\$ 269,000,000$ for non-automotive cases. A. Conard, N. Morgan, R. Pratt, Jr., C. Veltz \& R. Bombaugh, Automobile Accident Costs and Paxments 48, tab. 1-2 (1964) [hereinafter cited as Conard]. Many of the latter claims were, of course, against business concerns. Personal injury claims against individuals would probably show a considerably higher percentage of automobile cases.

49 The so-called treaty between the American Bar Association and various insurance associations so provides. See 3 Martindale-Hubbell LAw Directory 184 (1965). Apparently this is not always done. See R. Huntung \& G. NEUWIRTH, Who Suns IN NEW YORE GrYY? 113-16 (1962). Suits against the insurance company for wrongful refusal
} 
Liability insurance does not provide legal insurance for the motorist or victim of an accident who wants to sue. But the contingent fee, commonly used in such situations, does provide a kind of insurance protection. Plaintiffs are nearly always represented by a lawyer who agrees to provide his services for a percentage of the amount recovered either in settlement or after litigation. If there is no recovery, the plaintiff pays nothing for the legal services he has received. ${ }^{50}$ The contingent fee system thus spreads the cost of representing unsuccessful plaintiffs among the successful.

One of the principal arguments used to support the contingent fee system is that it provides competent legal service to people who could not afford the risk of paying a lawyer if they lost. In theory no one should be discouraged from consulting a lawyer if he has a potential claim. Accordingly, there is no need for legal insurance in contingent fee cases. That theory may be less than accurate. The defendant's insurance company may persuade a potential plaintiff to accept an inadequate settlement offer that would not be approved if the claimant had sound legal advice. If potential plaintiffs were free to consult lawyers as an insurance benefit, they might do so more readily than they presently do, and the settlements they would receive as a class might be more adequate. Furthermore, legal insurance would spread the cost of unsuccessful representation of plaintiffs over a larger population (all the insureds rather than just those who were successful), thereby making the total amount received by the injured plaintiffs larger. ${ }^{51}$

For purposes of initiating a system of legal insurance, contingent fee cases must be excluded because of their expense. Automobile cases are costly to prosecute as well as defend. Twenty-five to 35 per cent of the amounts received from liability insurance are consumed in collection expense, mostly lawyers' fees. ${ }^{2}$ Perhaps in time it will be possible to

to settle within the policy limits are increasingly common. See, e.g., Critz v. Farmers Insurance Group, 230 Cal. App. 2d 788, 41 Cal. Rptr. 401 (1965); Annot., 40 A.L.R.2d 168.

60 See F. B. Mackinnon, Contungent Fees for Legat Services (1964).

51 This assumes no increase in the number of unmeritorious cases brought by potential plaintiffs. It is possible that the lawyer, confident of being paid by legal insurance, would be more prone to bring cases of doubtful merit than the lawyer whose only chance of a fee is if he prevails. If so, the total number of unsuccessful cases would increase, thus diminishing the saving to successful plaintiffs.

52 CoNARD, supra note 48, at 54-57. The total payments made by insurance companies on automobile liability policies for 1960 were estimated there as $\$ 1,494,000,000$ and the claimants' collection expense as $\$ 471,000,000$. Franklin, Chanin \& Mark, Accidents, Money and the Law: A Study of the Economics of Personal Injury Litigation, 61 Colum. L. REv. I (1961) estimated the cost of collection at $35 \%$ of insurance payments in New York City. 
expand legal insurance to include contingent fee cases, but initially the increase in the risk exposure outweighs the possible social benefit.

2. Family Law-Divorce. Divorce cases are probably the most frequent problem of the middle class that involves substantial legal service expenses. ${ }^{53}$ Furthermore, the expense of divorce often comes at a time when the resources of the family unit will be strained. Although divorce is in the control of the insured, it is not likely to present serious problems of adverse selection. Like surgery, the cost of divorce is not the thing which discourages people from separating, ${ }^{54}$ although it may influence their decision to go through the formal divorce proceedings. ${ }^{55}$ Furthermore, it is possible that removing the financial obstacle to consulting a lawyer concerning a divorce might lead people to consult a lawyer earlier, when he would be in a better position to assist in reconciliation efforts. How effective lawyers are in this role is problematic, but presumably early consultation would improve their chances of success.

Divorce presents a novel problem of defining the insured unit. Presumably, legal insurance, like most health insurance, would protect the family as a unit, and therefore would be financing both sides of the litigation. There would be no conflict of interest problem because both parties would employ independent counsel, and, in truth, present practice amounts to the same thing since the legal expenses of both sides of a divorce now come from one pot. If the insurance benefit is conceived as going to the family unit before its division, rather than afterwards, there is no paradox in paying the legal fees of both husband and wife. It would be easier to justify paying the expenses of both rather than only one; if legal insurance is going to pay anything towards the cost of a divorce, it ought to pay all. ${ }^{56}$

53 The figures collected in the study referred to in note 10 supra suggest that family law problems are somewhere between $30-50 \%$ of the total reasons people consult a lawyer. By no means all who consult a lawyer about a divorce decide to obtain one, but to some extent any saving this occasions would be offset by covering both sides of the litigation. Most legal aid offices, if they take divorce cases at all, will represent only one side.

54 But see Enersen, Group Legal Services, 35 CAL. ST. B.J. 11, 16 (1960), where it is suggested that insuring the legal service in divorce cases "might seriously be attacked as a plan for encouraging divorce." No authority has been found to support that assertion. Contingent fees are held to be improper in divorce cases on the theory that the lawyer ought not to have a stake in separating the couple, see MacKrnnon, supra note 50, at $45-49$, but that rationale would not extend to legal insurance.

55 This might lead to a heavy initial run when legal insurance was first made available to any group. That has been the experience in some legal aid and OEOfinanced offices. There is substantial social value, however, in legitimizing de facto separations.

56 Paying the expenses of one side would be paying roughly one-half of the cost. 
Although including divorce as a benefit would probably be the most valuable part of the insurance, ${ }^{57}$ excluding it would have very little impact on marketability. "We will pay for your divorce" is not likely to be an attractive slogan for either employers or union leaders. Furthermore, divorce presents moral or religious problems to some who might resent paying for a benefit they felt themselves unable to utilize. In short, while there is some social value in providing coverage for divorce, it is likely to prove costly to the insurer, and it can be omitted without significantly reducing the attractiveness of legal insurance on the market.

3. Family Law-Miscellaneous. There are a number of other financially serious family law problems the incidence of which is much less than divorce. They include custody (other than incidental to a divorce), adoptions, guardianships, failure to support, paternity, and commitment proceedings. ${ }^{58}$ None of these is likely to be very expensive, but each can cost several hundreds of dollars. Failure to support perhaps should be excluded from coverage in those areas where a public agency, usually the district attorney, provides legal service without charge. ${ }^{59}$ Other than that, no form of legal insurance presently exists. As with divorce, it seems unlikely that people would adopt children or commit close relatives to a mental institution because the legal fees would be paid by insurance benefits. Thus the risk of adverse selection and of provoking socially undesirable conduct is low.

4. Real Property. In some parts of the country a lawyer is almost invariably brought into any transaction involving the transfer of title to real property in order to search the title and prepare the necessary legal documents. Elsewhere these functions are largely performed by title companies and real estate brokers. ${ }^{60}$ Where lawyers are used in real estate transactions, they may perform functions that are not strictly legal, such as finding sources for financing of real estate acquisitions.

It may be that insurance benefits would cover only a fraction of the total cost of any legal service, but there is nothing particularly magical about one-half.

57 Valuable in the sense that it is likely to be the most costly to the insurer.

58 The last can present problems about who is the insured. Commitment of the covered dependents would presumably be covered, but what of family members such as parents who are not dependent upon the insured, but for whom the insured feels responsible? Frequently the expenses of these proceedings would, in the absence of insurance, be borne by the person who initiated the proceedings.

59 See, e.g., statutes cited note 36 supra. Sometimes the service is restricted to those who are indigent, and, where that is the practice, the benefit should include prosecution of failure-to-support cases.

60 Lawyers seem to be losing a monopoly position insofar as filling out standardized conveyancing forms and title searching is concerned. See JoHnstone \& Horson, supra note 1 , at $180.81,273-314$. 
Within any one jurisdiction, however, the lawyer's role in residential real estate transactions is fairly well defined and standardized.

Assuming that the system accommodates in some way the fact that the wealthier are able to purchase homes and probably move more often, this benefit could be provided through insurance. The best reason for doing so is that it would encourage people who might otherwise not do so to consult a lawyer. In most instances, however, the lawyer's charges for services in connection with the purchase of residential property are not excessive, at least when measured in terms of the value of the property being acquired. The expense is thus one that is not worth insuring against in the sense that its financial impact will be relatively slight.

Some forms of legal insurance in connection with the ownership of real property are presently available. Title insurance companies undertake the defense of title suits to the extent of their coverage. Householder's liability policies customarily include provisions comparable to those in automobile liability policies, whereby the insurance company assumes the defense of claims arising out of defective conditions on the property.

A contingent fee is commonly used in condemnation proceedings, usually calculated on a percentage of the difference between the government's last offer and the amount finally awarded. ${ }^{61}$ The present system spreads the cost of legal services in defending condemnation suits among the relatively few whose property is condemned, and the legal fees significantly reduce the ultimate recovery of the property owner. Spreading the cost of representation among a larger group would thus have some social utility. To some extent this gain would be offset by the fact that a tax deduction would be lost if the expense of legal services in condemnation cases were provided by insurance. At present the legal fees are deductible from the award in calculating any capital gain. Insurance proceeds would not be deductible, since they were not spent by the taxpayer. To the extent that legal fees are paid indirectly by the government through a tax deduction, the expense is spread throughout the population generally. There has been some discussion of making reasonable attorneys' fees a recoverable item in condemnation proceedings. ${ }^{62}$ If that were done it would both eliminate the need for legal insurance for this purpose and also spread the cost of defending condemnation actions among the population generally.

61 MAcKInNON, supra note 50, at 28.

62 This has been done in Florida. Fla. Stat. ANN. \& 73.091 (Supp. 1966). Oregon includes lawyers' fees in the award unless the government's offer equalled or exceeded the amount judicially determined. ORE. REv. STAT. § 281.330 . 
5. Transmission of Property on Death-Estate Planning. The available figures show that the percentage of living people having wills is remarkably low. ${ }^{63}$ Nevertheless, an insubstantial amount of property passes by intestacy. A recent study of wealth transmission at death in Cook County, Illinois, indicated that only 15 per cent of deaths resulted in any probate proceedings and only 8 per cent had wills. Nonetheless, about 90 per cent of the wealth transmitted at death through probate was transmitted in testate estates. ${ }^{64}$ These figures may be somewhat misleading since they exclude the proceeds of life insurance and property held in joint tenancy, but they do suggest that the need for wills as a method of providing for the easy transmission of wealth on death is not very great. In the main the people most in need of a will for these purposes have one now.

If the only reason for consulting a lawyer about an estate plan were to provide for property transfer upon death, the problem of the unequal incidence of need for legal services because of the uneven distribution of wealth would be substantial. There are, however, other good reasons for planning for the event of death, such as designating the guardian of children. There is thus good reason for many people of modest means to consult a lawyer about the organization of their affairs on their death.

Lawyers have traditionally charged a very modest fee for this service, usually because the lawyer who drafted the will hopes to be appointed counsel for the estate, and expects that if he is, he will there make up the loss sustained in preparing the will. But in any event, except for the very few people who have substantial estates with major tax problems, the task of preparing a simple will is routine, and the fee accordingly is quite small and not worth insuring against. The only reason for including it as a benefit in any legal insurance program is again to encourage people who might not otherwise do so to consult a lawyer.

6. Administration of Estates. The cost of legal services in connection with the administration of estates is currently a controversial subject. For present purposes, it is not necessary to enter the debate beyond noting the fact that consultation with counsel before death can frequently reduce greatly the expense of transferring wealth on death.

Two problems noted earlier are of critical importance here: the difficulty of defining legal services and the relationship between wealth

63 The Missouri Bar Survey, supra note 14 at 130, 132, indicated that only 25 to $35 \%$ of the population surveyed had ever made a will. Earlier studies are cited in 6 R. Powell, REAL Property 606 (1968), showing a lower percentage for the population generally but a somewhat higher percentage for some professional people.

64 Dunham, Wealth Transmission at Death, 30 U. CHI. L. REv. 24I, 244 (1963). 
and the need for legal services. How much a lawyer does in connection with the administration of any particular estate depends in large part on the executor. If the executor is a corporate trustee or an experienced businessman, the lawyer's role is often merely to review transactions and prepare the formal legal documents. But if the executor is an unsophisticated widow, the lawyer may find himself performing a wide range of counseling services that reach well beyond what is normally thought of as the practice of law. And obviously, regardless of the executor, the amount and nature of the property (securities vs. a small business) will invariably have an important impact on the amount of legal services that is needed.

To the person who is planning his estate the cost of legal services is only a part of the total cost of transferring the ownership of his property on death. Barring some unusual development (e.g., a will contest) these costs can be predicted with a fair amount of certainty, ${ }^{65}$ and those who want to can know how much of their property will be consumed by such expenses as executor and legal fees and how much by taxes. Any such person is likely to consider the cost of legal services simply as one of the costs of administration and to treat them with executor fees and taxes as a package.

To a great extent these expenses can be provided for by buying life insurance payable to the estate. There is no real difference between life insurance and the benefit provided by a legal insurance scheme. Any legal service benefit would be limited to a sum adequate to pay the legal fees in connection with the handling of a routine estate of average size; in essence that amounts to a lump sum benefit, or life insurance. If that is the result, the benefit might as well be made sufficient to pay executors' fees as well as lawyers' fees since provision for all expenses of administration is presumably the benefit that people would desire.

Whether legal services to the insured's estate is worth including in the package of legal service insurance is highly debatable. There may be some utility in compelling people to think about the cost of administering their affairs after their death, but whether they should be induced to provide for that expense during their lifetime is basically a problem of life insurance planning, not legal services. Whether any particular person should make provision for this expense depends on the amount of his insurance, the number of his dependents and so forth. Legal fees in the administration of estates can, of course, unexpectedly consume a disproportionate amount of the estate. The will

65 Attorneys' fees in probate are normally fixed by the court and calculated as a percentage of the gross estate. Id. at 277. 
contest or complex problems which may be involved in handling the affairs of minor beneficiaries can be enormously expensive. The best protection against these contingencies, however, is not legal insurance, but adequate estate planning advice before death. Even the best of planning, however, will occasionally run awry. The difficulty of insuring against this contingency is determining the beneficiary. In many, if not most, instances the contest will be between members of the insured unit. It would not be difficult to provide legal insurance for the estate of the insured, but when the fees are charged to different members of his family, all or some of them dependents of the insured, the problems become very complex and probably could not be comprehensively covered.

7. Landlord-Tenant. Few middle- or upper-lower class tenants consult a lawyer before signing a residential lease. In very large part the terms and conditions of residential leaseholds are fixed by the landlord on the basis of standard forms developed by real estate owners' associations. The typical residential lease is substantially non-negotiable in all of its terms.

Though the terms may be standardized, the lease is often disregarded as a source of authority for the resolution of disputes, in favor of negotiation by the parties. If the dispute is one that does not yield to such informal resolution, various forms of self-help, such as rent withholding, may be resorted to by the tenant. Conduct of this sort can trigger lawyer involvement. Before then, lawyers may be used as a negotiating weapon by either party to write letters or make telephone calls. If the tenant is seriously in arrears in rent, legal proceedings to evict him may be instituted. For the poor, eviction proceedings are a serious problem, and much Legal Aid or OEO Legal Service work is done in this area. But evictions are likely to be less important to the classes of people who purchase legal insurance. Their landlord-tenant problems will more often involve protests concerning maintenance of the property and claims for minor personal injury or property damage connected with such maintenance.

The standardized lease, which favors the landlord but is largely disregarded in operation, tends to minimize the lawyer's role in representing the tenant. The law stated in the lease is unlikely to support the tenant's claim, although the landlord will frequently recognize an obligation unstated in the lease. The lawyer thus can only improve upon his client's capacity to help himself by threatening to upset the lease (an expensive operation unlikely to be attractive to the client) or by articulating more effectively the equities of his client's position. 
This kind of legal service is not worth insuring against because it involves very modest legal fees. One consultation, perhaps a telephone call or a letter, and the matter is closed.

8. Debtor-Consumer. The vast expansion of consumer credit has made the bulk of the income-producing population debtors in one form or other. Nearly anything can be bought on credit, and housing, automobiles, and durable appliances are routinely so purchased. Legal proceedings are brought to enforce the obligation to repay and various creditor remedies-foreclosure, attachment, garnishment, and repossession-will often trigger lawyer involvement on behalf of the consumerdebtor.

Resisting wrongful use of these remedies is a major function of the Legal Aid and OEO Legal Service offices. It would be wrong to assume, however, that these are problems only of the poor. Presumably because they have difficulty obtaining credit, the very poor are the least likely to be in debt. Installment credit is highest in the middle income groups $(\$ 2,000$ to $\$ 7,500)$ and most frequently encountered in those with large families at a fairly young age. ${ }^{66}$

The most common reason for lawyer involvement is failure to pay debts when due. This can arise from a multitude of reasons-unemployment, sickness, or marital difficulties, for example. Lawyers for the debtor frequently can do very little because the basic problem is an insufficiency of money, but lawyers are equipped to be useful especially to those who are unsophisticated in manipulating the credit system. They may be able to rearrange financing or to persuade creditors to wait. In some instances, putting the client in bankruptcy or setting up a wage earner plan may be appropriate.

Studies on the very poor suggest that there has been a tradition of abuse in sales practices and in arranging credit transactions sufficiently extensive that in many if not most instances credit transactions could be voided as fraudulent. ${ }^{67}$ It is doubtful whether this is as true of the classes accustomed to trading with reputable merchants. Nonetheless, sometimes the failure to pay stems not from an insufficiency of funds but from an exercise of the supposed right not to pay for goods that were defective or not as warranted. Lawyers could here assist people in utilizing the machinery of government to protect their rights.

For the most part this kind of legal service is not presently provided. From the lawyer's point of view, most of these problems are too small in amount to justify the time necessary to be expended,

68 Katona, Lininger \& Mueller, 1964 Survey of Consumer Finances 65-83. (Survey Research Center, Univ. of Mich. 1965).

o7 Caplovitz, supra note 38. 
although there has been some suggestion that if the practice were sufficiently specialized it could become economically attractive to lawyers. ${ }^{68}$ A very few employers provide a debt-counselling service to employees whose wages are garnished, and this may involve some legal assistance to the employee. ${ }^{69}$ With few exceptions, adequate legal service could be provided within the limits of one or two office consultations. In other words, the problems of debt are much like those of landlord-tenant and are unlikely to involve a great deal of legal service. The expense of legal service here is worth insuring against, not because the risk of loss is substantial, but rather as a way of encouraging people to use lawyers when they otherwise probably would not.

9. Bankruptcy. Bankruptcy proceedings frequently grow out of consumer debt involvement, especially if combined with marital problems. ${ }^{70}$ One recent study of personal bankruptcies in Ohio showed that over 90 per cent of the filings were made by employed persons ${ }^{71}$ with very low incomes (nearly 50 per cent under $\$ 4,000$ and over 85 per cent with incomes under $\$ 6,000),{ }^{72}$ reflecting a high concentration of personal bankruptcies in the unskilled and semiskilled occupation groups. ${ }^{73}$ Since the use of bankruptcy for non-business reasons depends to some extent on local law (if the garnishment and execution statutes of a state are very liberal to the debtor the necessity for going into bankruptcy is greatly diminished), the use of these data in other states is of doubtful validity.

Like divorce, bankruptcy is not the type of item which will make legal insurance attractive. ${ }^{74}$ For those few bankrupts who have assets, paying the lawyer's fee through insurance will do the insured no good, although it will increase the size of the distribution to creditors by reducing administration costs. For most bankrupts, however, the claim for lawyer's fees will survive the bankruptcy discharge and thus come

68 Fritz, How Lawyers Can Serve the Poor at a Profit, 52 A.B.A.J. 448 (1966).

69 Interview with D. Lascoe, Garnishment Administrator, Inland Steel Co., April 10, 1967.

70 G. BrunNer, Personal Bankruptcies (1965) provides the kind of data on incidence of one kind of legal problem that is not available in other areas. For the population studied (Ohio from 1956 to 1961) we have a breakdown according to occupation, income, marital status, and dependents that is of the type necessary to calculate an insurance premium. Unfortunately this is also one of the areas where there has been the greatest shift in incidence; the number of personal bankrupticies has been soaring, so that projections from past experience are probably very unreliable. See Countryman, The Bankruptcy Boom, 77 HARv. L. REv. 1452 (1964).

71 BRUNNER, supra note 70 , at 39 , tab. 7 .

72 Id. at 80 , chart 5 .

78 Id. at 45 , tab. 10.

74 Bankruptcies are apparently excluded from some fee financing schemes only because they are regarded as "improper." 
out of the debtor's future earnings; legal insurance will thus be a benefit to the insured. Whether there is social value in financing bankruptcies through legal insurance depends primarily on the attitude towards bankruptcy. If one takes the approach that people have a right to use whatever remedies the law provides, there is no substantial reason why bankruptcy proceedings should be excluded.

10. Collections. Although creditor claims by individuals are less frequent than consumer problems, many people find themselves from time to time with a modest contract claim which is uncollectable without the use or the threat of legal action. It may be that some people are foregoing enforcement because of a misapprehension as to the cost of using a lawyer. Legal insurance could stimulate litigation of small claims that people would otherwise not prosecute, at least not without the assistance of a lawyer. Some protection against abuse could be built into the system by restricting benefits to claims above a certain amount (perhaps the jurisdictional maximum of the small claims court).

11. Criminal Law. Of all legal services, the defense of criminal charges probably comes closest to the definition of an ideal insurable event. There is a clearly identified event to trigger insurance liability (the arrest); there is no difficulty in determining who is the insured; the legal service to be performed is relatively well-defined; the precipitating event is highly undesirable to the insured and not wholly in his control (it is possible he may not be guilty); and, unlike most of the other legal services discussed here, the expense of a criminal defense is generally substantial and can be ruinously high.

Involvement with the criminal law is most likely to result from operation of a motor vehicle. Limited forms of insurance for such occurrences are available through motor clubs and insurance companies. The benefit usually includes a modest bail bond and a short schedule of indemnity payments to defend against certain criminal charges, usually excluding those involving moral turpitude or driving while intoxicated..$^{75}$ The latter benefits are payable to the insured to

75 The plan of one motor club, for example, provides: "Reimbursement of the attorney's fee for appearance in court to defend you will be made in amounts up to, but not exceeding, those listed in this schedule. The scheduled amount does not represent the full fee which you may be charged by your attorney. Manslaughter cases, for defense $\$ 300$, if appealed an additional $\$ 200$; reckless driving cases, for defense $\$ 85$, if appealed an additional $\$ 75$; speeding cases, for defense $\$ 30$, if appealed an additional $\$ 30$; cases involving motor vehicles other than those listed, for defense \$25, if appealed an additional $\$ 25$. When more than one charge results from a single incident, reimbursement will be made for the trial charge calling for the largest payment. No reimbursement will be made for defense when charged with driving while intoxicated or under the influence of narcotics, leaving the scene of an accident, driving while under suspension or revocation, or any felony; for defending personal injury or 
reimburse him for legal expenses. As with commercial health insurance, no effort is made by the motor club to control the selection of a lawyer.

Many people would doubtless assume that if coverage were provided only for the defense of criminal automobile cases, there would be no substantial risk of having to pay for defense against any other criminal charge. That may well be wrong. The President's Commission on Law Enforcement and Administration of Justice recently took a different position:

Many Americans take comfort in the view that crime is the vice of a handful of people. This view is inaccurate. In the United States today, one boy in six is referred to the juvenile court. A Commission survey shows that in 1965 more than two million Americans were received in prisons or juvenile training schools, or placed on probation. Another Commission study suggests that about 40 percent of all male children now living in the United States will be arrested for a nontraffic offense during their lives. An independent survey of 1,700 persons found that 91 percent of the sample admitted they had committed acts for which they might have received jail or prison sentences. ${ }^{76}$

Thus, if legal service insurance were extended to dependents, thereby including juvenile criminal conduct, the benefit would probably seem valuable to nearly all. At any rate, a bail benefit would be particularly attractive to employers since it would help minimize absenteeism.

Gideon $v$. Wainwright has stimulated a vast expansion of the amount of legal work being done on behalf of persons accused of crime. ${ }^{77}$ Public defenders' offices are being expanded or opened at a very rapid rate. The federal government has started a program of compensating assigned counsel in criminal cases in the federal courts. In the main, attention has been focused on making sure that a lawyer is available for the indigent, with comparatively little attention paid to the problems of the person who is able to pay part of the expenses of his criminal defense. What constitutes an appropriate standard of indigency, whether it should vary with the nature of the case, and what obligation a defendant has to contribute to the expense of his defense, have

property damage suits; for bringing suits or collecting claims, or for payment of fines, court costs, witness fees, photos, etc."

76 President's Comm'n on Law Enforcement, The Challenge of Crime in a free SOCIETY v (1967).

77 See generally, L. Silverstein, Defense of the PoOR (1965); President's Comm'n on LAW ENFORCEMENT, TASK Force Report: The Courts 52-64 (1967) [hereinafter cited as TASK Force REPORT: ThE COURTS]. 
all been submerged in the more pressing problem of making a lawyer available. ${ }^{78}$ The formula developed by the federal government provides counsel to anyone "financially unable to obtain an adequate defense."79 This means that a person can be eligible for publicly financed legal assistance in cases having substantial trial and investigative costs, but not for cases where the defense costs less. Such a conception would be difficult to integrate into an insurance scheme, as would be the requirement, also in the federal act, that those who are able to pay only a portion of the expense should pay what they can. ${ }^{80}$

If the motor club precedent is followed, the schedule of benefits for the defense of criminal actions would look very much like the schedule of surgical benefits in a health insurance policy: $\$ 300$ for a burglary charge, $\$ 150$ for shoplifting, etc. That would provide the minimum kind of protection against a catastrophic legal expense. An alternative model would be like major medical with coinsurance, under which the insurance company would pay 75 or 80 per cent of the cost of defense, with the insured being responsible for some minimum amount. Because this would be more comprehensive, it would be more valuable, especially if the benefit included investigative expenses. In many jurisdictions the investigative resources of the public defender's office are very limited. ${ }^{81}$

The trend may be towards public financing of all criminal defense work, regardless of the defendant's capacity to pay. ${ }^{82}$ If a well established public defender's office did provide this service, the use of private counsel would not be prohibited, but the need for legal insurance would be eliminated.

78 "Another factor that varies greatly among the States is the method of determining eligibility for assignment of counsel. Rules of eligibility are usually unwritten, but in most courts financial ability to raise bail is considered, and in a few courts it precludes appointment of counsel .... Other factors frequently considered are wages or salary of the accused, ownership of real property, ownership of automobile and other tangibles, ownership of stocks and bonds and bank accounts. In many courts the test of eligibility is extremely simple, consisting of the single question, 'Do you have money to hire a lawyer?' Some courts require an affidavit of poverty or its equivalent before counsel may be appointed. A few courts, chiefly located in larger cities, employ a detailed written questionnaire or affidavit." Silverstein, Manpower Requirements in the Administration of Criminal Justice, TASK FORCE REPORT: THE COURTS 153 (1967).

7918 U.S.C.A. § $3006 \mathrm{~A}$ (a) (Supp. 1966).

8018 U.S.C.A. $\$ 3006$ A(f) (Supp. 1966).

81 Note, Right to Aid in Addition to Counsel for Indigent Criminal Defendants, 47 MrN. L. REv. 1054 (1963).

82 It can be argued, albeit weakly, that the equal protection clause is violated if only the poor are provided a publicly financed defense. See Department of Mental Hygiene v. Kirchner, 60 Cal. 2d 716, 388 P.2d 720, 36 Cal. Rptr. 488 (1964), judgment vacated, 380 U.S. 194 (1965), affd on rehearing, 62 Cal. 2d 586, 400 P.2d 321, 43 Cal. Rptr. 329 (1965). 
A revolution is likely to occur with respect to bail. The bail system has been coming under increasing criticism, and more and more suspects are being released on their own recognizance if they can show a connection with the community that makes disappearance unlikely. ${ }^{83}$ Naturally, if these reforms are generally adopted, the need for insurance for bail will diminish greatly.

The literature contains some suggestion that insuring the costs of legal defense would be contrary to public policy. ${ }^{84}$ The argument probably has its roots in the old authority prohibiting the use of contingent fees in criminal cases, ${ }^{85}$ and perhaps in the professional restrictions on advising clients to violate the law. ${ }^{86}$ Neither analogy is plausible, nor is it likely that people will be encouraged to engage in criminal conduct if they know that they will have a lawyer to defend them. The theory of Gideon v. Wainwright would seem to cut in the opposite direction, as does the older ethic of the profession that every man charged with a crime is entitled to as vigorous a defense as possible. ${ }^{87}$ The latter argument also eliminates one potential problem of legal insurance-with criminal cases there will be no need to screen cases for merit, as there may be with some forms of civil litigation.

12. Workmen's Compensation. The economics of legal service in workmen's compensation proceedings is complex because of the variation of practice under the different state statutes. The theory of workmen's compensation was that it would provide a fixed, relatively modest benefit for all workmen injured in the course of their employment. The hope was that strict liability for the employer and scheduled benefits for the employee would eliminate or reduce many of the incidental costs of recovery. Nearly all compensation cases are handled on a contingent fee basis ${ }^{88}$ and, for the most part, the fees are controlled by law. Fees may be restricted by limiting the percentage which can be charged, or they may be subject to approval by the agency which administers the law; in many states, the legal fee is sometimes made a separate part of the recovery in addition to the award. ${ }^{89}$

83 TASK Force Report: The CourTs 37-4I (1967).

84 Enersen, Group Legal Services, 35 CAL. ST. B.J. 11, 17 (1960).

85 Mackinnon, supra note 50 , at 52.

86 DRINKER, LEGAL ETHICS 151 (1953).

87 Id. at 142.

88 MLACKINNON, supra note 50, at 109. In many states the fee is contingent on the claimant recovering something more than the amount conceded to be due by the employer or insurance carrier. U.S. BuREAU OF LABOR Standards, AtTORNEY's FEes IN WORKMEN'S Compensation 9 (Bull. No. 220, Sept. 1960).

89 U.S. BuREAu of LABor Standards, supra note 88, at 11 . The situations which cause the attorney's fee to be added to the award include: "(1) the employer neglects or refuses to pay compensation within a reasonable time after compensation is due; (2) the defense 
In general, workmen's compensation proceedings have not been a financially attractive practice for lawyers. In order to make a comfortable living from workmen's compensation proceedings, lawyers have found it necessary to have a high volume of work so that they can achieve some economies of scale. It is common for lawyers to refer workmen's compensation cases to firms which specialize in the practice.90 Accidents involving minor injuries are often settled without lawyer involvement, but more serious injuries or deaths still require the active participation of lawyers. To some unknown extent, employees are no doubt accepting settlements that are less advantageous than those they could have achieved with competent counsel.

Labor unions have, of course, a substantial interest in workmen's compensation. No doubt it is common for shop stewards and other union officials to advise members who have been seriously injured to consult counsel before accepting a settlement, and, as noted earlier, the contingent fee will generally permit all to get access to counsel at no initial cost. At least one union has gone further: the United Mine Workers in Illinois employs a lawyer on a retainer to represent without charge to the individual all members in proceedings before the Illinois Industrial Commission. Each injured employee is given a form on which to report the accident to the lawyer, who translates these facts into the initial claim before the Industrial Commission. He then processes the claim through settlement negotiations and hearing if necessary. This turns into a high volume operation. Of the 8,500 working members of the union, 416 or 4.8 per cent had occasion to file a claim in $1964 .{ }^{.1}$ During that year a total of $\$ 528,885.12$ was received in awards. ${ }^{92}$

This program has a number of desirable attributes. It automatically gives the employee-member the advantage of experienced counsel in all cases and does not leave it to the injured workman to determine whether he needs legal services. Because the retained lawyer has a large volume of cases, he can organize the work for maximum efficiency and can train and use secretaries and others to handle routine tasks. There are dangers, of course, as well. The high volume of business can lead to impersonal treatment and to "wholesaling" of cases, and it is entirely

is without reasonable ground; (3) a review or an appeal is not supportable; or (4) employers are uninsured." Id.

90 See Gellhorn \& Lauer, Administration of the New York Workmen's Compensation Law (pt. 2), 37 N.Y.U.L. REv. 204, 218 (1962).

91 Petitioner's Brief for Certiorari at 15, United Mine Workers, Dist. 12 v. Illinois State Bar Ass'n., 389 U.S. 217 (1966).

92 Brief for Appellee at 8, Illinois State Bar Ass'n v. United Mine Workers, Dist. 12, 35 IIl. 2d 112, 219 N.E.2d 503 (1966). 
possible that some serious cases are getting inadequate attention because of the pressure created by cases of lesser significance. ${ }^{93}$ However, the end result is inexpensive service: for an average award somewhat in excess of $\$ 1,000$, the fee is less than $\$ 30$, and this charge, of course, is not deducted from the award but spread among the union membership generally.

A legal insurance system that included free choice of counsel could not provide such an inexpensive service. Unless the lawyer is experienced in workmen's compensation proceedings, a "routine" case involves an extensive amount of work. If legal specialties were recognized in the bar, the insured could be required to select his lawyer from those who were experienced in the field of workmen's compensation. In this way, both economies of scale and client free choice could be achieved.

The impact of an insurance system upon the distribution of representation costs in workmen's compensation cases is not simple. If the attorney's fee is added to the award, a legal insurance scheme would not expand the class of people paying the cost of representing claimants. The employers who pay for workmen's compensation insurance (or who self-insure) are already spreading that cost to the public generally. Legal insurance would increase the amount received by the injured workman if the legal fees are deducted from the amount received by the injured employee, but the same cost distribution could be accomplished by a general percentage increase in the schedule of awards.

The availability of legal insurance might induce more injured workmen to consult counsel, although at present the use of contingent fees suggests that relatively few claimants are discouraged from consulting a lawyer because of fear of the cost. ${ }^{94}$ Some probably believe they can net more by handling their own cases, and that group, of very indeterminate size, might be encouraged to use lawyers if legal insurance were available.

In summary, the objectives of legal insurance for workmen's compensation cases can be accomplished without a system of legal insurance. The cost of representing plaintiffs can be passed to the public at large either by making attorneys' fees a separate item added onto the award or by increasing the size of the awards by a percentage roughly equivalent to the contingent fee percentage. While legal insurance might not increase significantly the number of people who used a lawyer for processing substantial workmen's compensation claims, it

93 It is doubtful whether private employment of counsel works much better. See Gellhorn \& Lauer, supra note 90 , at 220.

94 About $20 \%$ of the cases in New York in 1959 were represented by counsel. Id. at 217. 
might discourage people from handling their own relatively modest cases, and this is, in itself, of doubtful social value, because there might be an increase in the cost of administering the program without much increase in the quality of administration.

\section{Governmental Relations.}

a. Taxation. The taxpayer of modest means can now get inexpensive assistance in the preparation of his income tax return. The government provides this service for nothing and, in addition, accountants have found it profitable to operate a service for preparing tax returns for a modest charge. Some lawyers also do this, although a "tax practice" usually means to lawyers advising business clients and high income taxpayers on rarefied problems infrequently encountered by the bulk of the population.

If assistance in preparing ordinary, reasonably uncomplicated returns were included as a benefit of legal insurance, it probably would absorb most of the available benefits even assuming a system that took full advantage of economies of scale. Considering the presence of a government program of advice supplied by the Internal Revenue Service and the modest charge of accountants, it would seem wisest to exclude advice on ordinary income tax matters from benefits.

On the other hand, unusual problems of taxation ought to be included. The main difficulty would be to distinguish the routine tax problem from the exceptional. One test which might be used is whether the insured's return is audited. If the government initiated the inquiry there would be less difficulty including a legal service benefit because the precipitating event would not be in the control of the insured.

b. Licensing, zoning, and other forms of administrative regulation. An increasing number of ordinary activities are under some form of governmental regulation. Urban property is almost always zoned and many jobs and activities are subject to restrictions which range from drivers' licenses to loyalty oaths. Any kind of government regulation can lead to legal problems but, for most, the incidence is slight and the cost minor. ${ }^{95}$ Nonetheless, questions can arise and frequently the role of the lawyer is to interpret rules and allay anxiety based on inexperience. Some types of employment present extra hazards of governmental intervention requiring legal services. Truck drivers, for example, rely heavily on their driver's license and, because they drive more, are more likely to be threatened with disciplinary proceedings.

Many of these administrative proceedings were conceived as not

95 A possible exception is immigration cases. 
requiring the use of lawyers. Applications for zoning variances, for example, are usually handled by architects or by the homeowner himself, and proceedings to suspend or revoke drivers' licenses are typically handled by the driver himself. Of late there has been increasing recognition that for some the assistance of a spokesman is essential if the person is to be heard at all. Lawyers are trained for the role of advocate, but many people seem hesitant to use them for these purposes, probably not because of the cost, but rather because they do not identify the problems as legal. Legal insurance of itself is thus not likely to expand greatly the utilization of lawyers' services for these kinds of proceedings. But it may help, and the expense per involvement should be quite low.

c. Government benefit programs. The Legal Aid and OEO Neighborhood Legal Services offices are spending an increasing percentage of their time encouraging lawyer involvement in the administration of welfare programs. Presumably the class of people covered by a legal insurance system would not have as much occasion to use a lawyer's service in welfare programs for the poor, but there are many programs, ranging from FHA financing to social security and Medicare, where the middle class could use legal assistance. The problem of eligibility in these benefit programs is frequently complex, and the services of a lawyer can be very important.

Some of the problems of the poor also trouble the more affluente.g., wrongful expulsion from school. Many people can deal with these problems by themselves and part of the reason why the Legal Aid and OEO programs have concentrated attention on these problems is that their clientele has considerably less than average capacity for selfhelp in dealing with government. Nonetheless, the middle classes also have their inarticulate unsophisticates who need advocates and interpreters just as badly as the poor. Again this problem is probably not so much financial as it is educational-teaching people to identify their problems as legal.

14. Claims Against the Employer or Union. Many disputes between an employee and his employer are presently serviced through his union, if he has one. Violations of the collective bargaining agreement, for example, will be handled through the union grievance machinery. Some public employee associations also provide legal services in personnel matters..$^{96} \mathrm{~A}$ public agency is also authorized in many states to accept assignments of wage claims and to prosecute them without charge to the employee. ${ }^{97}$ Claims against a union are undoubtedly

06 Cal. Bar. Comm., supra note 2, at 675-78.

97 E.g., statutes cited note 37 supra. 
much less frequent than claims against an employer, although the amount of litigation brought against joint union-employer welfare programs can be expected to increase as these become more general and important.

Neither the union nor the employer is likely to welcome financing a legal insurance program that subsidizes litigation brought against them. Perhaps the social utility of such an arrangement will become apparent in time, but such claims will probably have to be excluded from coverage for the time being.

15. Summary. No listing of this sort can be fully comprehensive. Another way of surveying the problem would be to think in terms of what the lawyer does rather than the event which precipitates his involvement. ${ }^{98} \mathrm{~A}$ lawyer can be an advisor, drafter, and negotiator as well as an advocate; and the listing above tends to emphasize the advocate's role. This role, however, is likely to be the most expensive one in connection with the personal problems of individuals. If all that is needed is advice or assistance in negotiation or drafting, the lawyer will usually be able to perform his tasks within a few hours.

But even where the lawyer is acting as advocate, this review shows that most of the need for legal services is either covered by liability insurance or a contingent fee or is likely to be inexpensive. In other words, the need for legal insurance to protect against catastrophic expenditures for legal services is not great. Apart from criminal law, there is no place where the typical upper lower- or middle-class citizen is likely to need expensive legal assistance (i.e., more than $\$ 1,000$ ) which is not available through liability insurance or a contingent fee arrangement. There are a number of situations, however, where people of modest means could use lawyers for relatively low cost services-one or two office visits, perhaps a brief court appearance. Divorce is the only commonly encountered need for legal service that is apt to stretch unduly a modest budget.

A system of legal insurance that excluded contingent fee cases and legal costs presently covered by liability insurance is thus likely to have its principal utility not in spreading the cost of an expensive service that lands on only a few, but rather in budgeting a low-cost service that nearly all could use. Its primary advantage would be to mitigate the present financial obstacle to consulting a lawyer, thus encouraging the use of lawyers for preventive purposes far more often than is now the case.

98 For a fuller description of lawyers' tasks approached in this way, see JoHNSTONE \& Hopson, supra note 1 , at 77-130. 


\section{A Model Legat Insurance Plan}

\section{A. Benefits and Exclusions}

In developing a model legal insurance plan certain general concepts have been followed. The first is that the plan should do as much as possible to encourage the utilization of lawyer services in ways that are socially desirable. That principle means chiefly that the plan should minimize the financial obstacle to consulting a lawyer in areas where lawyers' services are not commonly used. It also suggests that the plan should not duplicate or seek to supplant existing modes of financing legal services where the present methods are working reasonably well. Reaching out to pay through insurance for those kinds of legal services which the public presently can get without cost to the individual (as, for example, from a public defender) requires a separate justification for inclusion as a benefit. No private legal insurance scheme can spread the cost of legal services as well as the government's system of taxation, and if the public can get "free" legal service, it is not the cost of consulting a lawyer that is inhibiting utilization. Conservative insurance practice requires that the plan initially be limited in its benefits with the expectation that as experience accumulates, benefits would be added. Thus, in planning an insurance system primary attention has to be given to devices to limit risk exposure. Finally some attention must be paid to administrative and possible ethical problems. Substantial ethical problems are likely to arise from policing activities that invade the confidential relationship between the lawyer and the client-insured. The less policing required the better.

The following is one solution to the problem of designing a legal insurance system. Plainly it is not the only solution, nor necessarily the best. The purpose of outlining it here is to provide some basis for cost analysis and for evaluation of whether legal insurance would sell in competition with other kinds of services (e.g., dental care) or other ways of providing legal services (e.g., group legal services).

1. The Basic Benefit. The basic benefit would be the cost of consulting a lawyer for one hour per year on any problem except the preparation of tax returns. This would provide full coverage for most of the people most of the time; it would encourage the insured class to consult a lawyer when they were in doubt whether they had a legal problem; it would provide enough to solve most landlord-tenant, will drafting, real estate and consumer problems. The review of reasons why people consult lawyers suggests strongly that apart from divorce and crime there are very few legal problems which individuals are likely to have that cannot be solved in the course of one or, at the most, two or 
three office visits. ${ }^{99}$ Paying for the first visit, rather than the second or third, would be expensive to the insurer but it is the only way to overcome the financial obstacle that discourages people from consulting a lawyer early and especially for preventive purposes.

Apart from the exclusion of the preparation of income tax returns, it would probably be a mistake to limit the benefit in other ways, such as by attempting to exclude consultations on business as opposed to personal problems. For administrative convenience and because it would be difficult to make the limitations clear to policyholders, very comprehensive coverage (but limited in amount) is essential. It should be noted that this basic benefit is much more budgeting than it is insurance. The expense is not one that the insured class could not afford (all but the poorest can afford one hour of a lawyer's time), and it is an expense that a large percentage can expect to incur in any year. As experience develops it may be possible to expand the number of hours included in the basic benefit.

2. Excluded Services. ${ }^{100}$ The discussion earlier has suggested some areas which probably ought to be excluded from any coverage other than that provided by the basic benefit. They would be:

a. Legal services for which insurance is now commonly available. The largest class here is automobile and householder liability cases in which the insured is the defendant. The usual insurance device in these situations is an "other insurance" clause which, in substance, provides that if the insured has coverage against a particular risk by some other policy, coverage will be excluded from the second policy. An "other insurance" clause is not a wholly satisfactory mechanism in this context because it would not exclude those who had an opportunity to obtain liability insurance but did not do so. Very little can be said in support of insuring someone against the expenses of legal services when he has not had the foresight to insure himself against the liability itself. The exclusion clause probably ought, therefore, to be drafted more broadly

89 This conclusion assumes a client capable of assembling the relevant documents and telling a coherent story that sets forth with reasonable clarity all the relevant facts. In many instances that is no doubt a false assumption; frequently more than an hour would be spent getting the facts straight. An institutional publicity program that emphasized the importance of maintaining records and assembling all the relevant information before consulting the lawyer might help. There is no doubt, however, that the basic benefit, because it is a limited amount of a lawyer's time, will be most efficiently utilized by those who need it least and that the unsophisticated and confused are likely to use up much of the basic benefit in aimless explanations of problems rather than in getting the advice of lawyers.

100 This is an outline of possible coverage, not a draft of a policy. Some of the exclusions would not need to be stated in the policy since it presumably would be drafted in terms of risks covered rather than risks excluded. 
to exclude not only those who have liability insurance, but also those who could have purchased such other insurance. ${ }^{101}$

On the other hand, insurance protection ought to be provided for legal services in those instances where the liability insurer is in a conflict of interest position, as where the claim against the insured exceeds the liability policy limits, where the insured has a counterclaim or where the liability insurer has insured both parties in the accident. In those situations the insured has a need for legal services even though he has bought liability insurance. In many instances adequate protection would be provided by the basic benefit because all the insured would need was advice on the adequacy of settlement proposals or help in conducting simple negotiations. In some cases, however, more extended representation would be desirable.

b. Cases in which a contingent fee is normally used. This would exclude all personal injury, workmen's compensation and condemnation cases. The basic benefit would be useful in this area because it would encourage people to consult a lawyer about how to prosecute a claim and to review the adequacy of settlement offers made directly to the insured. Beyond that, however, including contingent fee cases would probably be very difficult because it would be both expensive and difficult to police.

c. Preparation of tax returns. This benefit, at least initially, probably has to be totally excluded (from the basic benefit, as well) because of the potential over-utilization and the availability of the Internal Revenue Service's publicly-financed advice.

d. Probate. For reasons discussed earlier, it probably would be advisable to exclude probate proceedings from coverage. The basic benefit would provide adequate coverage for most people on the death of some member of the family.

e. Wage claims and enforcement of support cases. In many jurisdictions some public agency will provide legal services to enforce wage claims and the obligation of support. On the theory that legal insurance is to supplement, not supplant existing methods of financing legal services, these claims ought to be excluded from coverage. The basic benefit will, of course, be available to direct the insured to the appropriate public agency for assistance.

\section{Other Possible Exclusions.}

a. Divorce. This is the expense of consequence most likely to be incurred. The available statistics suggest that somewhere between 30 to

101 An "other insurance" clause might well be used in the criminal area to avoid duplicate coverage with automobile club policies that provide a modest bail benefit and, sometimes, legal services in minor criminal traffic cases. See discussion at note 75 supra. 
50 per cent of the utilization of lawyers' services would be in divorce cases and probably the aggregate of divorce cases represents an even larger percentage of the total amount spent on legal services for individuals on personal problems. Excluding divorce has the advantage of limiting expense and avoiding the problems that might develop from those who are opposed to divorce on moral or religious grounds. On the other hand, excluding divorce will have the effect of eliminating from coverage the one legal expense that is both likely to occur and likely to be financially very difficult. To a limited extent, the basic benefit would help; it would at least provide protection for those who only wanted to consult a lawyer about the possibility of legal separation and it would, presumably, help somewhat in getting people into the hands of social agencies at an early stage when the agencies could be of maximum use in keeping the marriage together.

b. Criminal Law. ${ }^{102} \mathrm{~A}$ comprehensive benefit in criminal cases would include representation at all stages in any kind of criminal case, a bail benefit adequate to provide for the release of any insured accused of a crime, and a supplementary investigative-expert witness benefit that would cover incidental trial and trial preparation expenses. Obviously there are a number of ways of cutting down the benefit.

One way would be to exclude some of the more serious offenses, e.g., murder, rape, arson, and the like. The exclusion could be broadened by cutting out all offenses involving moral turpitude (which would leave mainly traffic and tax offenses) or all felonies. Reducing the benefit in this manner has very little to commend it other than that it avoids the objection that the insurance scheme was calculated to encourage crime. The financial burden of defense in the more serious crimes can be substantial and, especially for the innocent, insurance protection would be worth having. The incidence of serious crimes is quite low ${ }^{103}$ and the cost of providing coverage for those kinds of cases would probably be low, even though the cost per case would be high.

Another way of reducing benefits would be to provide them either before trial but not beyond, or provide benefits for representation at trial but not before. Coverage before plea would include coverage for consultation after arrest, representation at the preliminary hearing, if any, and at the time of plea. From the cost point of view, this cover-

102 For purposes of this discussion, juvenile problems probably ought to be classified with criminal cases. A case could be made for broader coverage in juvenile cases on the theory that it is limited to dependents and therefore largely out of the control of the insured. Also, legal services would probably be less expensive for juveniles than for adult defendants.

103 The cost is further reduced if recidivists are excluded, as they probably ought to be, by a clause restricting benefits to a single criminal offense per insured or dependent. 
age would be considerably more expensive than covering only representation at trial, although the cost per case would probably be quite low..$^{104}$ Combinations are, of course, possible, e.g., full coverage up to the point of plea, plus 50 per cent of the costs of trial.

What makes this problem particularly difficult is the presence of publicly financed criminal defense. In many communities the public defender will routinely represent all defendants up to the point of plea without making any substantial inquiry whether or not the accused can afford to retain his own counsel. Where that situation prevails, the benefit might well exclude pre-plea representation. Where that is not true, or where the services provided are so bad that anyone who could possibly do so (and who was knowledgeable) would want to engage private counsel, providing counsel before plea might well be more useful than at the trial stage. Even where a public defender is available, however, there may be a marketing reason for including representation in at least some kinds of criminal cases. The modest success of the automobile club indemnity policies suggests that at least some portion of the public wants protection against the cost of representation in some kinds of traffic cases. That benefit might also be significant to employers who would like their employees freed from the necessity of making appearances in court for minor traffic involvements. ${ }^{105}$

The extent of coverage for criminal cases probably depends in large part on local circumstances: the quality of publicly financed defense, the demand for representation in traffic cases, and, perhaps, the kind of juvenile proceedings. At the beginning it might be advisable to avoid this whole problem by not insuring any legal services in criminal cases and providing instead supplemental benefits other than legal services. This would include a bail benefit presumably limited to some extent (e.g., not more than $\$ 5,000) .{ }^{106}$ It could also include an investigator and expert witness benefit which would be valuable because

104 The initial figures from the federal Criminal Justice Act are suggestive of this conclusion. See Administrative OfFice of the U.S. Courts, Report to the Judicial Conference Committee to Implement the Crimital Justice Act (1967).

$105 \mathrm{It}$ is likely that many traffic cases will cease to be classified as criminal in the near future. The precise impact of this reform on the necessity or desirability of representation in traffic cases can only be speculated on at this point. It could well mean that if the person charged is to be represented at all he will have to pay for it; in such case an insurance benefit would clearly be useful.

108 How to design an appropriate bail schedule is getting increasingly complex. Illinois, for example, has completely revised its bail procedures (substantially eliminating the professional bail bondsman) in such a way as to reduce greatly the need for a bail benefit. See Oaks \& Lehman, The Criminal Process of Cook County and the Indigent Defendant, 1966 IrL. L.F. 584, 666-678. 
many public defender and assigned counsel systems have very inadequate investigative budgets. These expenses can be high and, except in the federal system, they are not generally available. ${ }^{107}$ Combined with the basic benefit, this plan would provide a significant protection for the bulk of insured population. An important benefit would be provided in the serious cases (where publicly financed legal service would in most places be available anyway). For minor criminal involvements, the insured would be able to make bail and could consult his own lawyer to determine whether he can or he should use the public defender or assigned counsel.

\section{Additional Benefits.}

a. Schedule benefit. A list of other events could be made up, the happening of which would entitle the insured to (l) an additional hour of consultation with a lawyer ${ }^{108}$ and (2) a maximum of one day in court. In its broadest form this benefit would become available any time the insured was named as a defendant in a civil suit (other than divorce), respondent in an administrative proceeding, arrested, or had his tax return audited. ${ }^{109}$ Alternatively the schedule benefit could be adjusted to particular triggering events with varying additional consultation and trial time allowed as benefits. For marketing purposes it might be better to use a long list of scheduled events, like the surgical schedule, rather than a broad summary statement.

In the beginning it would probably be best not to attempt to include any benefit that would compensate a lawyer for legal services that are not either in court or formal proceedings before an administrative agency. This would exclude all negotiation, research, trial preparation, and advice. These are the areas where the nature of legal services is least well defined and where there is the greatest potential of lawyer abuse. Possibly with time and experience these kinds of services could be included in some limited form, but initially it would probably be best to limit coverage to an objectively verifiable event relatively insensitive to lawyer abuse.

107 The amounts for these purposes spent under the federal Criminal Justice Act, 18 U.S.C. § 3006A (Supp. 1965), have been surprisingly low. See ADMINISTRATION OfFicE OF THE U.S. CourTs, supra note 104. On the need for investigative assistance, see Note, Right to Aid in Addition to Counsel for Indigent Criminal Defendants, 47 MinN. L. REv. 1054 (1963).

108 If a "scheduled" event occurred, such as being named as a defendant in a civil suit, the insured would be entitled to consult for one hour without the hour counting against the basic benefit.

109 If some kinds of criminal cases were included (e.g., traffic cases), they could also be included as a scheduled benefit permitting the insured-accused to an hour's consultation and a day in court. 
b. A "major" trial benefit. The schedule benefits could be suppiemented by an additional benefit that paid the cost of days in court after the first day, up to a maximum of 10 days. This would pick up the few instances in which the insured was in the position of plaintiff, but as plaintiff the insured would be required to finance the first day of legal service expense in court. If the insurance plan excludes criminal, divorce, contingency fee, and the defense of most personal injury cases, the occasions for which an individual would be in court for more than a day would be very few indeed and this benefit would thus be quite cheap to the insurer. For defendants, this benefit could be tied to the schedule benefit (much the way major medical is tied to regular, surgical, and hospitalization insurance) so that the package would leave the insured a co-insurer of only a small portion of the risk of legal service expenses in court.

5. Administrative and Ethical Problems. There is a danger that this array of insurance benefits will stimulate litigation by ill-prepared lawyers and thus worsen the clogged condition of many trial courts. Conceivably some lawyers would aim towards litigation in situations where without insurance they would not, and do a minimal amount of pretrial preparation because only in court would they be entitled to insurance benefits. A comparable kind of unprofessional conduct has been alleged in places where the practice is to compensate insurance defense counsel on a per diem basis. There is some evidence that where this is common, the incidence of settlements after trial has officially started is higher because the lawyer's compensation increases if the case goes to trial. ${ }^{110}$ This danger is very difficult to evaluate, just as it is difficult to measure the extent of unnecessary hospitalization where health insurance benefits are keyed to hospitalization of the insured. A simple increase in hospitalization does not prove abuse; in some instances no doubt it was useless, but in many others hospitalization significantly improved, or could reasonably have been thought likely to improve, the quality of care, and thus an increase in hospitalization because of insurance cannot automatically be called socially wasteful. Similarly, pushing a case into court probably affects the ultimate settlement and it thus has a kind of social utility.

This package by no means provides complete coverage against the risk of paying for legal services. Apart from the exclusion of criminal, divorce, and contingent fee cases, it provides nothing beyond the basic benefit for advice, negotiation, and legal research. Nor does it protect the insured against the expenses of trial preparation, court costs, in-

110 H. Zeised, H. Kalven JR., \& B. Buchholz, Delay IN THE Court 107 (1959) [hereinafter cited as ZEISEL, KAIVEN \& BuchHoLZ]. 
vestigator and expert witness fees (except in criminal cases), or any of the costs of appeal. Before dismissing the plan as hopelessly inadequate, it may be well to remember that health insurance, although very widely held and greatly expanded from its earliest form, now pays only 36 per cent of private payments for physicians' services; that most people still have only hospitalization insurance, surgical and "regular" health insurance, a package which excludes most forms of outpatient care, drugs, and many other kinds of medical expenses. In other words, less than comprehensive coverage is the norm, and it would be surprising if legal insurance could start with a plan that was ambitiously comprehensive.

The basic benefit and the schedule benefit would frequently be insufficient to cover the full cost of representation. This creates a potential problem that may be serious: How much is the lawyer going to charge for services not covered by insurance? The lawyer is in a most advantageous bargaining position. For the insured-client to change lawyers would be both painful and expensive, since the lawyer who has received the insurance benefits is familiar with the problem. There is a danger that the lawyer will inflate his fee for services not covered by insurance to take advantage of his bargaining position with the result that the value of the insurance benefit will be considerably reduced. The ideal solution would be to require the lawyer to limit his fees to an agreed upon hourly rate as a condition of participating in the insurance plan.

To a limited extent the form of the basic benefit can discourage this kind of depreciation of the value of the insurance. If the benefit is stated in terms of a dollar amount for not more than one hour of legal service it will probably serve to define the hourly rate and, unless the lawyer is willing to cheat on reporting his time, it will be hard for him to change his hourly rate. For example, if the basic benefit were in the form of $\$ 35$ for one hour of legal service most lawyers would probably accept that as full payment for the first hour. ${ }^{111}$ They would, of course, be free to charge more, but the liability of the insurer would be lim-

111 Many lawyers charge less for the first hour, and minimum fee schedules sometimes reflect this "loss leader" method of pricing. For example, the minimum fee schedule for the South Side Bar Association of Chicago in 1962 listed the basic hourly charge for noncourt work as $\$ 30$ but allowed $\$ 15$ for the "preliminary" consultation. The 1960 minimum fee schedule of the State Bar of Wisconsin similarly suggested a \$5 per hour initial consultation fee with an $\$ 18$ per hour standard charge. Probably the practice of charging a small initial fee is more common than the minimum fee schedules would suggest. To prevent this practice from defeating the value of legal insurance requires that the benefit for the initial consultation be little, if any, below the going rate for hourly charges. 
ited to that amount. Few lawyers would have the temerity to charge a higher hourly rate for services after the first hour.

The schedule benefits would be restricted to compensation for court appearances, e.g., $\$ 150$ per day of trial, $\$ 100$ for a half day, $\$ 35$ for appearances on motions, with no benefit for preparation or research. Nothing would prevent a lawyer from charging more, but probably for most the benefit would define the fee. The risk of abuse here is relatively slight, and it could be reduced by eliminating coverage for motion appearances and by making the benefit less than the going rate for court appearances so that the incentive to engage in litigation, or to prolong it once there, would be minimal.

Most of the plans that are comparable to this model plan for legal insurance have found it necessary to insert some sort of reviewing body that authorizes expenditures beyond a minimal amount. ${ }^{112}$ Such "third party" intervention creates a host of problems which can be characterized either as political or ethical. The doctors call it lay control of medicine; lawyers are likely to protest on the ground that it invades the confidentiality of the lawyer-client relationship. The model plan has been designed to avoid this problem by abandoning any effort to police the "basic benefit" and by limiting the other benefits to reimbursement for the expense of representation in court or before administrative agencies. That evasion has its costs; it means that only services that are readily verifiable by appearances in court or before an agency are included, and the various services that lawyers provide in their offices are excluded. If a third party were to authorize expenditures based on the nature of the problem, expenses such as trial preparation, negotiation, legal research, as well as appeal costs, could be included. But, as with health insurance, it probably is best to start with indemnifying the cost of objectively verifiable services, like surgery.

\section{B. How Much Will the Model Legal Insurance Plan Cost?}

The lack of reliable figures on the incidence of legal problems makes any projection of possible costs largely guesswork. Even if reliable data were available on how often people were presently using lawyers the

112 The English Legal Aid and Advice program requires advance screening on legal merits as well as financial eligibility, and, of course, fees are in general rather rigidly controlled in England. See Johnstone \& Hopson, supra note 1, at 508-21. The various OEO-financed Judicare schemes operative in this country require committee approval if the lawyer's services exceed a specified amount. The Culinary Workers plan in Los Angeles provided only consultation service in civil cases and representation through the preliminary hearing in criminal matters. For representation in criminal trials, committee approval had to be obtained. Interview with A. Schulman, April 26, 1967. 
increase of use because of the availability of legal insurance would still be unknown. The following, accordingly, must be understood as no more than a very rough approximation of possible costs.

1. The Basic Benefit. Only two studies are known which attempted to measure the incidence of legal problems of a population through time. For these purposes both studies are inadequate, but both found that during a year, about 25 per cent of the population studied had a problem about which a lawyer was consulted. ${ }^{113}$ Some doubtless consulted a lawyer about more than one problem, and some no doubt had their problems disposed of in less than an hour of a lawyer's time. For purposes of estimating the cost of the basic benefit, both would reduce the cost. That reduction in incidence, however, would probably be more than outweighed by an increase in use of lawyers because of the presence of insurance. On this very inadequate base it seems likely that the basic benefit would be used by somewhere between 25 and 40 per cent of the insured group. The other variable is the hourly charge of lawyers. If we assume a range of $\$ 25$ to $\$ 35$ for the first hour, the cost of the basic benefit for an insured group of 1,000 would be:

Basic Benefit

\begin{tabular}{cccc}
\hline $\begin{array}{c}\text { Rate } \\
\text { of use }\end{array}$ & $\begin{array}{c}\text { Hourly } \\
\text { Charge } \\
\$ 25\end{array}$ & $\begin{array}{c}\text { Hourly } \\
\text { Charge } \\
\$ 30\end{array}$ & $\begin{array}{c}\text { Hourly } \\
\text { Charge } \\
\$ 35\end{array}$ \\
\hline $25 \%$ & $\$ 6,250$ & \multicolumn{1}{c}{$\$ 7,500$} & $\$ 8,750$ \\
$30 \%$ & 7,500 & 9,000 & 10,500 \\
$35 \%$ & 8,750 & 10,500 & 12,250 \\
$40 \%$ & 10,000 & 12,000 & 14,000 \\
\hline
\end{tabular}

2. The Schedule Benefit-Consultation. The schedule benefit is more difficult to predict. If the scheduled benefit occurred (most broadly, if the insured were named as a defendant in a lawsuit other than divorce, respondent in an administrative proceeding, arrested or had his tax return audited) he would be entitled to an hour of consultation with a lawyer and that consultation would not count against the basic benefit. Some would not need to use the scheduled benefit because one hour would be adequate and they would not use their basic benefit during that year; others would have more than one occasion to use the schedule benefit. Undoubtedly the use of the schedule benefit would be less than for the basic benefit, but how much less is pure guess. If we assume that 10 to 25 per cent would use the schedule benefit for consultation and that the hourly charge ranged from $\$ 25$

113 These are the Koos study of the middle class and the survey of the Culinary Workers, both discussed in the study referred to in Cal. Bar Comm., supra note 2, at 65557. 
to $\$ 35$, the cost for an insured group of 1,000 could range from a minimum of $\$ 2,500$ to a maximum of $\$ 8,750$.

3. Schedule Benefit-Trial. The schedule benefit would also pay for the lawyer's charge for one day of trial if the matter went that far, or, with criminal cases, for bail and investigative-expert witness fees. This benefit would be used less than the schedule consultation benefit. A study of 4,000 accident cases in the Michigan courts showed that only 15 per cent of the cases filed actually went to trial..$^{114}$ A similar study in New York Gity showed about 30 per cent ${ }^{115}$ survived to trial. Personal injury cases, of course, would not, for the most part, be included, but assuming that a 15 to 30 per cent ratio of survival from filing to trial is also applicable to other kinds of cases, ${ }^{110}$ that would mean that only 1.5 to 7.5 per cent of the insured class would have occasion to use the schedule benefit for trial purposes. ${ }^{117}$ The other variable is

114 ConAro, supra note 48 , at 241 , fig. 7-2. In "serious injury" cases only $5 \%$ actually began trial. Id. at 184, fig. 6-1.

116 ZeIsel, KALven \& BuchHolz, supra note 110, at 32-33. These figures are not precisely comparable to those cited in CoNARD, supra note 114, because the New York figures are divided according to whether the case was settled before assignment to trial, and some cases are settled after assignment but before trial.

116 The New York study also computed these figures for non-personal injury cases and the figures are roughly comparable. The 15 to $30 \%$ survival rate is supported to some extent by the following table of dispositions of cases in the California Superior Courts:

GALIFORNIA SUPERIOR COURTS: MANNER OF DISPOSITION BY TYPE OF PROCEEDING

Fiscal Year 1965-66

\begin{tabular}{|c|c|c|c|c|}
\hline \multirow[b]{3}{*}{ Type of proceeding } & \multicolumn{4}{|c|}{ Per cent of total dispositions } \\
\hline & \multirow[b]{2}{*}{ Total* } & \multirow[b]{2}{*}{ Before Trial } & \multicolumn{2}{|c|}{ After Trial } \\
\hline & & & Uncontested & Contested \\
\hline Total, all proceedings & 100 & 28.0 & 61.9 & 10.1 \\
\hline Probate and guardianship & 100 & 1.3 & 97.9 & .8 \\
\hline $\begin{array}{l}\text { Divorce, separate maintenance } \\
\text { and annulment }\end{array}$ & 100 & 11.5 & 82.3 & 6.1 \\
\hline $\begin{array}{l}\text { Personal injury, wrongful deat } \\
\text { and property damage }\end{array}$ & 100 & 80.8 & 9.0 & 10.2 \\
\hline Eminent domain & 100 & 56.3 & 23.9 & 19.8 \\
\hline Civil actions not elsewhere & & & & \\
\hline classified & 100 & 36.7 & 54.7 & 8.6 \\
\hline Insanity and other infirmities & 100 & 5.0 & 90.9 & 4.1 \\
\hline Juvenile & 100 & 5.0 & 87.4 & 7.6 \\
\hline Criminal & 100 & 69.0 & 一 & 31.0 \\
\hline
\end{tabular}

- Percentages may not equal total because of rounding.

Source: Ad. Office Cal. Courts, Annotated Report 201, tab. 19 (1967). These figures, of course, include business cases as well as personal litigation.

117 The weak link in this calculation is the percentage of people who would use the schedule-consultation benefit. 
the average trial benefit. The model plan hypothesized a maximum of one trial day at the rate of $\$ 100$ for a half day, $\$ 150$ for a full day. If an average trial benefit is assumed to be $\$ 125$, the cost of the schedule trial benefit could range from $\$ 1,875$ to $\$ 9,375$.

4. The Major Trial Benefit. The maximum liability would be for 10 days of trial at $\$ 150$ per day, or $\$ 1,500$ in any one case. Very few would reach that level. The average length of trial for non-personal injury cases in New York City was 9.8 hours. ${ }^{118}$ If a trial day of 4 hours is assumed, that would mean an average liability after the first day of a little more than $\$ 150$. The incidence would probably be less than the schedule trial benefit, perhaps somewhere in the range of 1 to 5 per cent. ${ }^{119}$ If so, the cost for 1,000 insured with an average benefit of from $\$ 150$ to $\$ 200$ could range from $\$ 1,500$ to $\$ 10,000$.

5. Administrative Costs. The cost of administering an insurance program of this nature is somewhat easier to estimate. The loading charge in group health insurance is about 10 per cent of the total benefits paid out. ${ }^{120}$ An experimental program of this sort would doubtless have a higher administrative cost, and the necessity of having some reserve for unexpected liability would indicate that a 20 per cent loading charge for a start would not be inappropriate. Twenty per cent of the total of the highest estimated figures would be $\$ 8,425$. The total of the highest estimates thus works out to about $\$ 50,000$ for coverage of 1,000 , or a per insured cost of $\$ 50$ a year.

\section{Will It Sell?}

There are two ways of approaching the question: Would the model legal insurance plan sell? The first is to look at alternative services or benefits that the potential purchasers (unions and employers, for the most part) might buy. The other way is to examine alternative ways of financing legal services, such as group legal services.

1. Alternative Uses of Fringe Benefit Money. Fringe benefits are usually discussed in terms of percentage of payroll. If an average annual pay of $\$ 6,000$ is assumed ${ }^{121}$ the folowing table suggests what the competition would be:

118 Computed from ZeIser, KaLven \& BuchHolz, supra note 110, at 36, tab. 11 .

119 There would be some plaintiff's work in here as well, since the major benefit would include paying the cost of plaintiff's trial after the first day. The number of cases, however, would be very small since contingent fee, divorce, criminal, and business cases would all be excluded.

120 H. SOMErs \& A. Somers, Doctors, Patients, AND Fealth Insurance 272 (1961). This is, of course, for group enrollments; a much higher loading charge is necessary for individual coverage.

121 The median family income in 1963 was $\$ 6,265$. U.S. DEP'T OF CoMMERcE, BUREAU of the Census, Statistical Abstract of the United States 341, tab. 468 (1965). 
Benefit

Percentage of Payroll

(average annual $\$ 6,000$ )

$\begin{array}{lr}\text { Legal Insurance } & .8 \% \\ \text { Life Insurance (I year's pay-term) } & 1.0 \\ \text { Basic Health (Employee only) } & 1.0 \\ \text { Major Medical (Employee only) } & 1.0 \\ \text { Basic Medical (Dependent coverage) } & 2.0 \\ \text { Major Medical (Dependent coverage) } & 2.0 \\ \text { Long-term Disability (60\% of pay less social security) } & 5 \text { to } 1.0 \\ \text { Vacation (per day) } & .4 \\ \text { Dental (excluding orthodontia) } & 2.5 \text { to } 4.0\end{array}$

The health and life insurance benefits are fairly common. Longterm disability insurance is less frequently found and dental coverage is rare. Given freedom of choice many, if not most, employees would probably choose more vacation time over either long-term disability or legal insurance. Some union officials have been persuaded that it is in the membership's interest to be protected against long-term disabilities and thus to include that benefit in the package of fringe benefits. At the moment, it probably would be difficult to persuade union officials to bargain for legal insurance if the membership did not already have a very complete coverage against medical expenses, including long-term disability. Even where medical needs are adequately insured, most union leaders will be unenthusiastic about legal insurance since the membership generally does not appreciate its need for legal services.

Employers, on the other hand, may find legal insurance attractive. A number now provide a vaguely comparable kind of benefit through house counsel and there is some experience which suggests that the availability of legal assistance improves employee morale and reduces absenteeism. ${ }^{123}$ For some employers the total fringe benefit package (including vacation time) runs up to 25 to 30 per cent of payroll. Where that is true, an additional 1 per cent for legal insurance is plainly within the range of the possible. If experience proves its desirability to either the membership of a union or to employers, a demand for it as a fringe benefit may begin to emerge. Without a demonstration that proves the utility of legal insurance, however, it is only possible to speculate about future growth. For the moment it is enough to know that a cost for legal insurance of less than 1 per cent of payroll is feasible.

122 Interview with Messrs. Davis H. Roenisch and William V. Quirk of Arthur Stedry Hansen, Consulting Actuaries, May 1967.

123 Cal. Bar Comm., supra note 2, at 679-81. 


\section{Competitive Ways of Financing Legal Services.}

a. Fee financing. It was the dentists, rather than the doctors, who inspired the plan of financing legal fees by bank loans. The first plan for lawyers became operative in mid-1965 in Erie County (Buffalo) New York, ${ }^{124}$ and a number of other bar associations are now trying similar plans. ${ }^{125}$ As yet it is too early to make confident assertions about success because neither the bar nor the public has become accustomed to the idea.

The idea has its roots in the belief that much of the public has become so accustomed to purchasing goods on credit that trying to sell modestly expensive services such as dental work or legal services on any other basis is fighting the standard pattern of consumer expectations. The objective of the plan is to translate a fee into an installment debt payable over time. The Erie County Bar Association plan is a cooperative arrangement worked out between a bank and the bar whereby the lawyer fills out a brief credit questionnaire which is telephoned into the bank. Assuming that the bank approves the client's credit, an installment note is signed by the client. The loan is technically from the lawyer, but the bank agrees to accept an assignment of the paper at a specified discount. The bank also agrees to permit the lawyer to recapture the paper before beginning enforcement proceedings and to waive any defense it might have as a holder in due course with respect to the quality of the legal services.

The fee financing plan is not available in contingent fee cases or, as a matter of practice, in bankruptcy cases. ${ }^{126}$ After a year's operation about half the lawyers eligible to participate in the Erie County plan had signed up and something over 200 loans had been made in an average amount somewhat in excess of $\$ 500$. No breakdown of the kinds of cases is available, but, as might be expected, the largest class of cases is divorce, followed by criminal law and real estate matters. ${ }^{127}$

In very large part fee financing is post-event budgeting of the same expenses that a legal insurance scheme would prepay. The loading factor for administering an insurance scheme would roughly equal interest and credit services charges in fee financing. Fee financing pro-

124 The plan is described in detail, with copies of the various forms, in the 1965 Award of Merit Entry of the Bar Association of Erie County, New York, entitled: "Legal Service Financing Plan."

125 Plans have been started in Toledo, Ohio; Flint, Michigan; San Francisco, California; and doubtless in other communities.

126 The prohibition on loans in contingent fee cases is stated in the plan, supra note 124, at 13; bankruptcy cases are not accepted as a matter of practice. Interview with J. $B$. Walsh, Executive Director, Bar Association of Erie County, April 12, 1967.

127 Id. 
vides a broader coverage; it can include all kinds of cases, court costs, and other incidental charges and the full range of lawyer services. On the other hand, beyond providing a convenient way of paying for the service, fee financing does nothing to encourage broader utilization of lawyer services, especially in the preventive area. The basic benefit in legal insurance would presumably encourage people to see a lawyer when they thought they might have a legal problem.

Some of the ethical problems presented by fee financing are shared by legal insurance. Fee financing has been opposed on the grounds that it tends to commercialize the profession and tends to fix fees. ${ }^{128}$ Furthermore, if the cooperating banks advertise the availability of loans to finance legal fees an advertising problem might be presented. An insurance company would face the same problem if it attempted to advertise legal insurance for selling purposes or if it publicized the benefits to members of a group which had purchased legal insurance. It is difficult to evaluate these ethical problems. A number of ethics committees have decided that fee financing is not improper. ${ }^{128}$ The traditional conservatism of the bar probably explains some of the opposition. Any scheme of legal insurance is certain to encounter comparable hostility. ${ }^{130}$

128 The Board of Governors of the California State Bar on March 21, 1966 adopted a resolution stating that, while payment of legal fees by means of a financing or loan plan by pre-arrangement with a lending agency had been approved by the Ethics Committee of the California State Bar, the Board of Governors opposed any such plan because of the dangers of commercialism, the possible interference with the attorney-client relationship, and the danger of lowering the honor and dignity of the profession. The Board of Governors also indicated that the plans would tend to conflict with professional standards because of the temptation to increase the amount of the fee to cover any agreed discount rate (ABA Canon 12), the possibility of violating confidences of the client by revealing information concerning his financial ability and the nature of his legal problem (ABA Canon 37), and the possibility that the practice might become tantamount to fee splitting (ABA Canon 34).

129 The Committee on Professional Ethics of the American Bar Association recently delivered its opinion that: "It is not per se unethical for a local or state bar association to approve and for lawyers to participate in a plan for financing legal fees, provided adequate precautions are taken to see that the plan is formulated and administered within the canons of ethics." 54 A.B.A.J. 476 (1968). In so doing, they approved the fee financing plans of the bar associations of the state of Arizona, the cities of Philadelphia and Toledo, and the counties of Erie (New York) and Macomb (Michigan) as well as the proposed plan of the Denver Bar Association.

130 See Enersen, Group Legal Services, 35 CAL. ST. B.J. Il (1960), suggesting, in discussing the possibility of legal insurance in criminal cases, that: "There is probably something wrong in hiring a lawyer first and committing a crime afterward. If a group should undertake on a major scale to provide legal defense against future criminal charges, I suppose that the entire group might become accessory before the fact, if not co-conspirators." Id. at 17.

It is worth noting that Mr. Enersen later chaired the California Committee which studied Group Legal Services and his views shifted in time to be considerably more 
b. Employer financing. A substantial number of employers provide some kind of legal service for their employees. A survey of 508 companies in 1964 showed that 15 per cent provided assistance in the preparation of income tax forms, 4 per cent in the preparation of wills, and 9 per cent other forms of legal service. ${ }^{131}$ A 1950 study of corporate legal departments showed that of the 52 companies studied, 11 gave no advice to employees on personal problems, 35 would give advice on minor problems, and 6 provided a relatively comprehensive service. ${ }^{132}$

Physical arrangements influence the extent to which the employer can make legal assistance available to employees. To provide a lawyer requires, first, an organization big enough to have a house lawyer ${ }^{133}$ and, second, that the bulk of the employees work in the same building as the house lawyer. Where these conditions prevail it is, apparently, not uncommon for house counsel to provide a service much like the basic benefit of the model legal insurance plan: an initial consultation that informs the employee whether he has a legal problem, solves it if the problem is simple, and, if not, directs the employee to places where he can get such further assistance as he may need.

A very few employers provide a different kind of service to employees whose wages have been garnished. This is in part debt counselling, but it can reach beyond that to assistance in arranging other forms of financing, protesting the garnishment on the ground that it was procedurally irregular, or otherwise helping the employee to straighten out his debt problems. ${ }^{134}$

If some employers regard this kind of service as worthwhile from a personnel point of view, others would probably find attractive a system of legal insurance that provided comparable benefits. The wartime experience of one employer who provided legal service to employees in an effort to improve morale and keep the work force on the job sup-

sympathetic to the concept of group legal services. As guardians of tradition, bar association ethics committees have tended to be very conservative and to look doubtfully on any new developments. Hostility to legal insurance can thus safely be predicted, although in the long pull both it and fee financing seem to present no substantial ethical problems so long as the client retains complete freedom in the selection of his lawyer. If client choice of lawyer is restricted, however, the canons as presently written would be violated, although the wisdom of that ethical restriction has long been subject to question. See, e.g., H. DRINKER, LEGAL ETHICS 159-167 (1953).

131 National Indus. Conf. Board, Personnel Practices in Factory and Office: Manufacturing tab. 96 (Studies in Personnel Policy No. 194, 1964).

132 National Indus. Conf. Board, Corporate Legal Dep'ts 7 (Studies in Business Policy No. 39,1950$)$.

133 It is, of course, possible to retain an outside lawyer for this purpose; but that is not commonly done.

134 Interview with D. Lascoe, Garnishment Administrator, Inland Steel Corp., April 10, 1967. 
ports this judgment. ${ }^{135}$ To the employer whose physical arrangements would not permit providing house counsel (or who is concerned about the attitude of the bar on the subject), ${ }^{136}$ legal insurance would be a means of achieving much the same objectives. To the employee, of course, a "free" benefit of employment would be preferable to a deduction from his wages for legal insurance, but in the long run the two are substantial equivalents. The advantages of an employer-provided lawyer, which relate mainly to economies of scale, are essentially similar to those discussed below in connection with group legal services.

c. Group Legal Services. The most serious competitive threat to legal insurance is here called group legal services, where one or more lawyers for a salary or retainer restrict their practice to servicing the legal needs of the members of a group, in this instance most likely the membership of a labor union. No reliable information exists on the present extent of group practice of this nature. ${ }^{137}$ A number of unions, especially locals, retain counsel who is available to the membership at no or minimal charge for consultation in a wide range of matters. ${ }^{138}$ Some go beyond that to provide representation in some kinds of cases. Informal arrangements are probably even more common where a lawyer tacitly agrees to provide consultation service at no or very slight charge in exchange for having referred to him by shop stewards and other union officials such fee-generating cases (mainly personal injury) as may come up. Data about these arrangements are difficult to obtain because the organized bar has regarded them as unethical. ${ }^{139}$ The decision in United Mine Workers District 12 v. Illinois State Bar Association, ${ }^{140}$ invalidating Canon 35's sweeping prohibition against group legal services, is likely to stimulate at least a somewhat more open operation of such offices by unions.

The competitive advantages of group legal services are substantial.

135 CaI. Bar. Comm., supra note 2, at 639, 679-68I.

136 Canon 35 has generally been construed to prohibit a lawyer, paid by the employer, from rendering legal services to employees on their personal problems. See H. DRINkER, LEGAL ETHICS 162-67 (1953).

137 The California study on group legal services attempted to survey the extent of group practice at the time in California and reported its admittedly incomplete findings in Cal. Bar Comm., supra note 2, at 669-89.

138 A number of group legal service plans are discussed in Paulson, Report on the Needed Legal Services Project, I Procendrngs Ass'N Amer. LAw Schools 292, 300-03 (1966). The U.S. Bureau of Labor Statistics, which maintains a considerable file of collective bargaining agreements, does not classify legal services for purposes of its records. It is the impression of the Commissioner that union plans to relieve the burden of legal expenses are primarily local union endeavors. Letter from A. Ross, Commissioner of Labor Statistics, to the author, March 16, 1967.

139 H. Drinker, Legal Ethics 162-67 (1953); but see note 149 infra.

140389 U.S. 217 (1967). 
In very large part the legal problems of individuals are repetitive low cost items. If a lawyer has enough divorce, landlord-tenant, garnishment, small estate, or workmen's compensation cases, he can become familiar with the relevant body of Iaw and the kinds of factual background information he will need, and systematize his work in such a way as to reduce greatly the cost of servicing any particular case. ${ }^{141}$ This is especially true if he has enough of the work to justify training and using non-lawyers to make the factual inquiries, fill out simple forms, and the like. The lawyer retained to represent a large group can do just that, and in the process he will be able to provide more legal services at less cost. ${ }^{142}$ A legal insurance scheme, because it will use lawyers from the entire bar, cannot provide comparable economies of scale. ${ }^{143}$

The other great advantage of group legal service is that it names the lawyer to be consulted. Those who do not know a lawyer are understandably reluctant to consult just any lawyer listed in the telephone book or even one suggested by a lawyer referral service. To the layman, the lawyer for the group seems to have been selected as being qualified and can be presumed to have an interest that goes beyond the particular client of providing adequate service at a reasonable cost.

Group legal service also has an inherent capacity to control the charges for legal service that legal insurance could achieve only through regulation of fees and review by some agency that authorized expenditures above some minimal amount. A lawyer working on a retainersalary for a group has no motivation to inflate the amount of work that he does for any particular client. The danger, if there is one, is the other way: that he will tend to give less service than a case deserves in order to minimize his work load. In this respect group legal service is

141 See Fritz, How Lawyers Can Serve the Poor at a Profit, 52 A.B.A.J. 448 (1966), for a description of how one lawyer manages to make a living out of cases most lawyers would reject as economically unworthy of their time. It is worth noting that divorce and workmen's compensation are in many places now largely in the hands of specialized practitioners who frequently confine their practice to those fields. With divorce, this is in part a matter of taste-a domestic relations practice is generally looked down on; with workmen's compensation, it is more likely to be a matter of economic necessity because of the regulation of fees. See note 88 supra. JoHNSTONE \& Hopson, supra note 1 , at $543-45$, strongly urge the development of high volume operations.

142 The model legal insurance plan was estimated to cost $\$ 50,000$ for an insured group of 1,000 . Fifty thousand dollars would easily pay for the salary of a lawyer, rental of his office space, and other overhead items. He could provide more service to the 1,000 than would be covered by insurance.

143 If lawyers recognized specialties it would be possible to achieve some economies of scale with legal insurance by requiring the insured client to consult a specialist. But apart from a few exotic fields such as patent law and admiralty, there are no officially sanctioned specialties in law. 
much like a public defender's office. A public defender can, generally speaking, provide more legal service for less than an assigned counsel because of economies of scale. ${ }^{144} \mathrm{~A}$ public defender of necessity has to live within a budget and, accordingly, he is forced to make economic decisions as to how he can best organize his work to give maximum service. ${ }^{145}$ A group legal service office can similarly be budgeted with reliance placed on the lawyers to make sensible professional judgments when to stop providing legal services. That kind of gross budgetary control will supply the restraint on lawyer abuse that is so difficult for legal insurance. A group legal service office could thus provide the kinds of service that are only vaguely legal (and presumably utilize nonprofessionals where the demand was great enough) ${ }^{146}$ as well as supply much more legal advice and negotiating assistance. ${ }^{147}$ Those kinds of lawyer services are hardest for legal insurance to accommodate because it is nearly impossible to police them against lawyer abuse.

Group legal service would suffer from some of the same disadvantages that trouble public defender's offices. Unless it is adequately staffed, the quality of group legal service is likely to seem casual and abrupt to individual clients and there is a substantial risk, especially in repetitive kinds of cases such as workmen's compensation, of "wholesaling" cases with resulting injustice to individuals.

Ethically, legal insurance has the advantage over group legal service

144 This is, of course, assuming that assigned counsel are compensated at a reasonable figure and that the community is large enough to generate enough indigent business to permit volume economies. See Abrams \& Petrie, California, 2 DEFENSE OF THE POOR IN Griminal Cases in American State Courts 63-73 (L. Silverstein ed. 1965).

145 In some respects a group legal services office would have an advantage here because its freedom of action would be somewhat greater. A public defender has no choice but to represent the indigent where the law requires representation for a constitutionally valid conviction. He thus must be in attendance when the defendant's plea is taken and when he is sentenced, although as a practical matter it may well be that he could accomplish more by allocating the limited time available to other functions.

146 Debt and marriage counselling, for example, might well be done cheaper and more effectively by persons specially trained for those roles rather than by lawyers.

147 Group legal services also has a potential for growth that has been carefully elided thus far in all discussions of the subject: it could be another way of financing personal injury litigation on the plaintiff's side. There are substantial economies of scale to be made in grouping plaintiff representation. Insurance companies use non-professionals (adjusters) to collect evidence and settle claims and there is no reason why large groups of plaintiffs could not do the same thing. This economy is added to the advantage of spreading the cost of plaintiff representation over a larger group (all the group rather than just those members who are successful plaintiffs). Legal insurance could do the spreading also but only at a cost that, at least at the moment, seems prohibitive. The long range potential of group legal services in personal injury cases is the possibility that it will provide a force within the profession interested in simplifying and reducing the cost of claim settlement. 
because it preserves the tradition of free choice of lawyer. ${ }^{148}$ Whether that tradition could pay its way in the market is an open question. Some people doubtless would be willing to pay more to have their own lawyer rather than one selected by someone else; how many feel that way, and whether their feeling is strong enough to compensate for the economies of scale possible with group practice, is not known. Now that the Supreme Court has held the present ethical rules unconstitutional, a market place evaluation of the concept of free choice of lawyer may be possible. ${ }^{149}$

To potential purchasers of legal services, legal insurance has two other advantages over group legal services. The first is that the buyers (union officials and management, for the most part) would be spared the responsibility of administering group legal service. Whoever selects the group lawyer is necessarily in the position of making some warranty of quality; he will have to review complaints and exercise such fiscal control as may be necessary. Many unions have threatened from time to time to establish their own medical service facilities but few have actually done it. Partly that is because medical facilities are expensive, but it is also because managing such an enterprise is an enormous administrative headache hard to justify over a long period. Group legal service offices would not be as difficult to establish because they would be less expensive and there would be fewer personnel involved, but the problems of administration are nonetheless substantial..$^{150}$

For some unions, legal insurance would also make it easier to provide comparable service to all the membership. A national union is necessarily conscious of the problems of making fringe benefits roughly comparable throughout the country. This has been one of the attrac-

148 If legal insurance covered divorce cases, it could finance both sides, which group legal service offices probably could not easily do because of the conflict of interest.

149 The independent health insurance plans, led by Kaiser, made peace with organized medicine through the device of treating "free choice of plan" as the equivalent for ethical purposes of "free choice of physician." The bar may well have difficulty with that precedent. A union determined to establish a group legal service office might improve its ethical position by offering its membership legal insurance with free choice of lawyer as an alternative to enrollment in a group legal service plan. No one can know how such an election would come out, but it is unlikely that the bar would be as willing as the doctors were to accept the compromise of letting people make their own choice. Nearly everyone has some relationship with a doctor which will encourage him to choose an indemnity-insurance plan over a closed panel. That appears to be less true of the relations between lawyers and individuals, with the probable result that nearly all would opt for group legal service over legal insurance.

150 Legal insurance as a fringe benefit would avoid all the problems involved in disturbing the manifold informal arrangements that exist between individual lawyers and union officials, especially at the lower levels in the hierarchy. A group legal service office would necessarily disrupt those relationships with political consequences that would tend to discourage union negotiators and management from wanting to get into the tangle. 
tions of commercial health insurance, which provides the same dollar value of benefits to all the membership regardless of where they live. For a union to attempt to provide group legal service to all would require establishing relations with lawyers throughout the country, and for some local units it might be difficult to achieve significant economies of scale because of small local membership. Legal insurance would tend to equalize these problems although the disparity of legal costs between different jurisdictions would make any national equality extremely difficult to engineer..$^{151}$

\section{The Insuring Entity}

The insurance business is extensively regulated at the state level. In most states it would not be possible for a commercial insurance company to issue a legal insurance contract without enabling legislation. With bar association support, presumably there would be no great difficulty in getting some form of legislation passed. It could follow the precedent of the Blue plans and provide for a separate, professionally controlled non-profit entity exempt from both taxation and much of the insurance law, or it could take the form of authorizing the issuance of legal insurance contracts by commercial insurers. In either instance some regulation of terms, financial responsibility, and perhaps rates and benefits can be expected either by state insurance officials or other state agencies.

The exact form of such legislation is highly technical, and it would be premature at this stage to attempt a detailed discussion of the problems. A certain amount of organized bar control can easily be built into the legislation; that was one of the devices used by organized medicine to restrict the growth of "independent" closed panel health plans. ${ }^{152}$ Short of legislative prescription, state and national bar organizations can be very influential by proposing model acts or by specifying minimum standards for the terms and conditions of legal insurance plans. ${ }^{153}$

151 An attempt to set up a national system of legal insurance would present a host of problems most difficult to resolve equitably. There are wide disparities not only between Iarge and small communities (reflecting the different overhead costs) but also between jurisdictions based on local practice. In some states lawyers are routinely used in all real estate transactions, elsewhere only rarely. Bail schedules vary widely. Adoptions in some places require extensive legal assistance, elsewhere they are utterly routine. The catalogue of potential problems is vast; it might well be, however, that the disparities would tend to average out. Without comparing legal insurance schemes in operation in various communities it is impossible to make anything more than wild speculations as to the feasibility of a national legal insurance system. Obviously, the first thing to do is work on a local basis.

162 H. Somers \& A. Somers, Doctors, Patrents, and Health Insurance 322-23 (1961). 153 A model Blue Cross statute, proposed by the Commission on Hospital Service, 
It would also be possible to develop service-oriented plans closely comparable to the independent closed-panel medical plans where a group of lawyers agreed to provide specified kinds of legal services to the membership of a group (e.g., a union). This is a compromise between what has here been called group legal services and legal insurance. ${ }^{154}$ It is like group legal services in that it restricts the client's choice of lawyer, and, like group legal services, it has the advantage of gross budgetary control which would permit the provision of more advice, negotiation, and research assistance as benefits. Like legal insurance, the cost would be spread among the membership of the client group, and, presumably, legal services would be utilized in ways that are not common now. At present, of course, such an independent service plan would present serious ethical problems because of the restriction on the client's choice of lawyer. Whether lawyers should use insurance laws to create legal barriers in support of their ethical norm of free choice of a lawyer is doubtful.

\section{CONCLUSTON}

Legal insurance is a possible way of financing legal service for individuals of modest means. A plan can be constructed that would not be too costly to be sold. For the most part the services that would be purchased through insurance are low cost, preventive law services that the public is not now buying. The primary value of legal insurance would be as a way of encouraging people to use more legal services. For selected groups, legal insurance would be more attractive than group legal services, but, in general, legal insurance cannot achieve the economies of scale possible through group legal services. Legal insurance, accordingly, is far from a complete answer to those concerned about the economic threat of group legal services, nor is it likely to revolutionize the economics of law practice.

was very influential. $I d$. at 294. Standards for approval were issued by both the American Hospital Association and by the American Medical Association.

154 A service-oriented plan with a closed panel would fit the definition of group legal services that has been used in this paper. See note 16 supra. By providing service rather than indemnity benefits, it might conceivably avoid the technical label of insurance. See California Physicians' Service v. Garrison, 28 Cal.2d 790, 172 P.2d 4 (1946). But in all other respects such a plan would be comparable to a legal insurance plan. If the client group were large enough, significant economies of scale might be possible. 